\title{
Short-time work in the Great Recession: firm-level evidence from 20 EU countries
}

\author{
Reamonn Lydon ${ }^{1}$, Thomas Y. Mathä ${ }^{2}$ and Stephen Millard ${ }^{3 *}$
}

\author{
* Correspondence: \\ stephen.millard@bankofengland.co. \\ uk \\ ${ }^{3}$ Bank of England, Durham \\ University Business School and \\ Centre for Macroeconomics, \\ Durham, UK \\ Full list of author information is \\ available at the end of the article
}

\begin{abstract}
Using firm-level data from a large-scale European survey among 20 countries, we analyse the determinants of firms using short-time work (STW). We show that firms are more likely to use STW in case of negative demand shocks. We show that STW schemes are more likely to be used by firms with high degrees of firm-specific human capital, high firing costs, and operating in countries with stringent employment protection legislation and a high degree of downward nominal wage rigidity. STW use is higher in countries with formalised schemes and in countries where these schemes were extended in response to the recent crisis. On the wider economic impact of STW, we show that firms using the schemes are significantly less likely to lay off permanent workers in response to a negative shock, with no impact for temporary workers. Relating our STW take-up measure in the micro data to aggregate data on employment and output trends, we show that sectors with a high STW take-up exhibit significantly less cyclical variation in employment.
\end{abstract}

Keywords: Firms, Survey, Crisis, Short-time work, Wages, Recession

JEL classification: C25, E24, J63, J68

\section{Introduction}

Short-time work (STW) programmes are schemes aimed at preserving employment in firms temporarily experiencing weak demand. The Great Recession saw a significant increase in the number of employees on STW schemes and the number of countries introducing or extending schemes. Furthermore, even where such schemes were not available, for example within the UK, employers still acted to reduce the hours of their workers while maintaining their links with them through the use of zero-hour contracts. This paper investigates the impact of STW schemes and the temporary use of short-time work more generally in Europe. The research makes two key contributions. First, we document the extent to which short-time work schemes were used by firms to adjust labour demand over the 2010-2013 period, whether as part of a government-sponsored STW programme or not. Second, we quantify the relationship between STW scheme take-up and firm characteristics, worker characteristics, economic factors, such as the scale and nature of shocks, and institutional factors. The main institutional factors we consider are the importance of employment protection legislation and the extent of downward nominal wage rigidities at the country-sector level. The research builds on existing cross-country studies of STW schemes by Arpaia

(c) Bank of England, Central Bank of Ireland and Banque centrale du Luxembourg. 2019 Open Access This article is distributed under the terms of the Creative Commons Attribution 4.0 International License (http://creativecommons.org/licenses/by/4.0/), which permits unrestricted use, distribution, and reproduction in any medium, provided you give appropriate credit to the original author(s) and the source, provide a link to the Creative Commons license, and indicate if changes were made. 
et al. (2010), Hijzen and Venn (2011) as updated by Hijzen and Martin (2013) and Boeri and Bruecker (2011). However, to our knowledge, this is the first study to use firm-level cross-country data to look at the determinants of STW usage and take-up.

To examine these issues, we draw on the data from the third wave of the Wage Dynamics Network survey (WDN3). ${ }^{1}$ The WDN3 dataset contains micro data on over 25,000 firms across 25 EU countries, surveyed during 2014. The survey asks firms how they adjusted their labour demand and wage levels in the face of the economic shocks experienced during 2010-2013. WDN3 data allow us to examine both subsidised and unsubsidised reductions in working hours at the firm level. In our analysis, STW occurs when firms use subsidised reductions in working hours to reduce labour inputs.

To provide context for our paper, in the next section, we give an overview of research on the take-up and impact of STW schemes during the Great Recession. In Section 3, we present a simplified version of the model in Balleer et al. (2016), within which we can think about some of the theoretical implications of STW programmes. We discuss the WDN data, together with the data we use on the detail of existing STW programmes and employment protection legislation in our group of countries, in more detail in Section 4. Section 5 presents our empirical framework and results. Section 6 concludes.

\section{Shocks and adjustment of labour inputs: the evidence}

Substantial research output concerning short-time work and its effects has sprung up following the Great Recession. Renewed interest in short-time work is primarily motivated by differences in the extent to which employment and average hours fell across different countries in response to the crisis. In particular, take-up of STW schemes during the Great Recession is often cited as one reason for the German 'employment miracle' during the recession. ${ }^{2}$ In Germany, flexible working-time arrangements are a deeply embedded characteristic of the labour market, leading some to suggest that this contributed to the different employment response to the crisis. Balleer et al. (2016) suggest that the standard STW scheme in place in Germany acts as an automatic stabiliser and so contributed to the muted response of unemployment to the crisis. However, Burda and Hunt (2011) and Möller (2010) downplay the contribution of STW programmes attributing more relevance to the increased use of work-time accounts than STW programmes.

As documented in Arpaia et al. (2010) and Boeri and Bruecker (2011), in many countries, policy changes that affected the coverage, eligibility and compensation rules relating to STW schemes became increasingly common during the recession. For example, in 2008/09 in Germany, there were changes to the length of time a worker/firm might avail of these mechanisms (i.e. 6, 12 or 24 months), the proportion of income preserved, and who bore the costs (i.e. the firm or the State). Brenke et al. (2013) show that workers in sectors most exposed to world demand shocks, such as those related to the car industry, benefited most from these changes. Using a time-series approach to generate a counterfactual employment scenario, Herzog-Stein et al. (2013) conclude that the cyclical job losses would have been around $40 \%$ higher in the absence of STW schemes. Relating specifically to scheme alterations, Balleer et al. (2016) conclude that the discretionary changes to the STW programme in Germany made during this period had no effect on the unemployment rate. One of the contributions of our paper to this literature is to show exactly how characteristics of schemes relating to eligibility conditions, duration and compensation affect the likelihood of firm take-up. 
Two cross-country studies, by Hijzen and Venn (2011) and Boeri and Bruecker (2011) use aggregate data to analyse the net benefits associated with STW schemes. Hijzen and Venn (2011) show that the reduction in permanent employment during the crisis was smaller in those countries with STW schemes, after controlling for the intensity of the recession. At the same time, there is some evidence that average hours of permanent employees fell relatively more in countries where short-time work schemes were operational. Hijzen and Venn (2011) also show that STW schemes have less of an impact on the hours and employment of temporary employees, relative to permanent employees. In this paper, we also differentiate between the relative impact on permanent versus temporary employees.

Boeri and Bruecker (2011) document the impact of short-time working schemes during the crisis across countries. They report a dampening effect of the short-time work take-up rate on the response of employment and identify a threshold of $1.5 \%$ of a reduction in GDP above which short-time working helps prevent employment losses. Using these parameter estimates, they calculate the number of jobs potentially saved by participation in the schemes. Their estimate of the 'jobs saved' by the schemes is lower than the number of employees taking up schemes, which suggests a degree of deadweight loss. Closely related to our own cross-country exercise, Boeri and Bruecker (2011) also draw on German establishment data for 2009 to investigate the impact of firm business conditions, structural characteristics, human capital investment and labour force composition on firm take-up rates. They show that STW take-up rates are mainly affected by contemporaneous or anticipated shocks rather than by long-lasting structural problems - in other words, STW schemes are primarily a response to cyclical as opposed to structural shocks. STW usage increases with the size of the firm, its export share, the share of employees with vocational training and its share of research and development activities. Interestingly, a higher share of employees with university degrees is associated with a lower short-time working take-up. Shares of employees on part-time or fixed-term contracts appear to reduce the share of firm employment in short-time work, supporting the hypothesis that there exist stronger incentives for firm participation in the case of permanent employment. Finally, the role of collective pay agreements on the extent of firm participation is not clear, although there is some evidence that the average firm take-up rate falls in its presence. Using the same dataset as Boeri and Bruecker (2011) for the years 2003 and 2009, Crimmann et al. (2010) get similar results in terms of the firm and worker characteristics that are most associated with usage of STW schemes.

In this paper, we use survey data across 20 countries to obtain a sense of how general are the results of Boeri and Bruecker (2011) and Crimmann et al. (2010). That is, is the extensive use of such programmes a 'German thing' or are the same firm characteristics important in all countries in which such schemes exist? For example, Abraham and Houseman (2014) provide new evidence for the U.S., suggesting that STW schemes saved jobs in a number of states during the recession. In particular, in manufacturing, where STW is most predominantly used, the response to declining labour demand was smaller in STW than in non-STW states. Using questions available only for Luxembourg from the same dataset used in this paper, Efstathiou et al. (2018) find that in Luxembourg $25 \%$ and $20 \%$ of employees involved in short-time work would have lost their job without this arrangement in 2008-2009 and 2010-2013, respectively. 
Extrapolated to the whole economy, this would translate to approximately 2400 and 920 jobs saved, corresponding to $0.7 \%$ and $0.3 \%$ of employment in the respective sub-periods.

The extent to which STW schemes can promote efficient outcomes is likely to depend on other institutional features of a country's labour market and labour market policies. Burdett and Wright (1989) compare the relative efficiency of labour market adjustments under two unemployment insurance schemes: one where unemployed workers only receive benefits and another where short-time compensation is paid to workers on reduced hours. As noted earlier, they find that the first system can lead to inefficient layoffs, whereas the latter can lead to inefficient hours per worker. Using a similar framework, van Audenrode (1994) looked at the interaction between subsidised reductions in hours and firing restrictions. He argued that it is only when you have suitably generous, mandatory redundancy payments that STW schemes will result in efficient adjustment of hours with no employment adjustment. In this paper, we also consider this interaction between firm take-up of STW schemes and employment protection legislation (EPL).

STW schemes are generally designed as temporary measures; they help firms to limit inefficient separation of otherwise viable jobs during temporarily adverse economic conditions. An important question for these schemes is the extent of their deadweight and displacement effects, as well as potential inefficiencies. Deadweight effects arise when STW schemes subsidise jobs that would have been preserved in the absence of a subsidy. Displacement effects give rise to longer-term inefficiencies when STW schemes preserve jobs that are not viable without a subsidy, hindering labour mobility and efficiency enhancements (such as re-training). On the potential inefficiencies in STW schemes, Cahuc and Nevoux (2017) argue that the expansion of STW schemes in France during the recession primarily benefitted large firms that were recurrent STW users. They find it to be an inefficient way to insure workers, as it involves those firms less affected by demand fluctuations subsidising those firms more affected by demand fluctuations. This leads to too many firms in those sectors more affected by demand fluctuations relative to the social optimum and to lower output as a result. They show that experience-rated STW schemes eliminate the inefficiency. Balleer et al. (2016) also note that discretionary changes to an existing STW scheme lead to deadweight effects, since the marginal job has already been preserved as a result of the existing scheme. In our paper, we use cross-country variation in STW schemes, whether they are announced as being temporary or not, to examine this issue. Using German firm-level data Cooper et al. (2017) show that, while STW schemes preserve employment, they also come with output losses as a result of allocative inefficiencies when vacancy-filling is reduced. In contrast, Kopp and Siegenthaler (2018), using Swiss quarterly establishment-level panel data, not only report evidence that STW prevents rather than postpones layoffs, but also that the savings from reduced unemployment benefit payments may be large enough to fully compensate the payments related to STW.

\section{A model of hours in the presence of STW schemes}

The rationale for short-time work programmes stems from the idea that temporary fluctuations in demand may lead firms to engage in excessive layoffs. Layoffs may be excessive in the context of demand volatility due to the quasi-fixity of labour as an input of production (Oi 1962). A temporary drop in demand necessitates an adjustment on the input side in the short-term, which will eventually be reversed once demand has rebounded. If, in 
the short-run, capital is fixed and labour variable, then employment will bear the entirety of that burden in the short run. However, this may not be the efficient outcome due to fixed costs of hiring and firing workers. These expenses need to be amortised over the course of the employment relationship and, thus, require a sizeable fall in demand and, in turn, in the value of the worker's marginal product to justify a layoff on efficiency terms. In the case of high hiring and firing costs, it can be more efficient to hold onto this labour and reduce average hours in response to a negative demand shock. To capture this idea, Balleer et al. (2016) put forward a simple search and matching model of the labour market. In what follows, we discuss a simplified version of their model with the aim of generating some hypotheses about what matters for firms' decisions to make use of short-time working. These hypotheses will then be examined in our empirical work below.

Following Balleer et al. (2016), we assume that the value of a worker to the firm depends on the number of hours worked $(h)$, aggregate demand $(a)$, an idiosyncratic shock to the value generated by the worker $(\varepsilon)$ and the wage $(w)$. We assume that the shock $\varepsilon$ is additive, is drawn from a random distribution that is firm-specific, whose mean is denoted $\bar{\varepsilon}_{f}$, and is iid across workers within each firm and across time. We make the mean of this distribution firm-specific, to capture the idea that some firms employ more highly skilled workers than others. To make the hours choice meaningful, we follow Balleer et al. (2016) and add a quadratic cost of employing workers for more than 'full-time hours' (normalised to 1). We assume that all workers in the firm will work the same number of hours. In that case, the firm solves the problem for optimal hours by considering the worker with mean productivity, i.e. with $\varepsilon$ equal to $\bar{\varepsilon}_{f}$. Now, we can write the value to the firm of the worker with mean productivity as:

$$
J\left(a_{t}, \bar{\epsilon}_{f, t}\right)=\operatorname{Max}_{h_{t}}\left(\left(a_{t}-w_{t}+\bar{\epsilon}_{f, t}\right) h_{t}-\phi\left(h_{t}-1\right)^{2}+\beta E J\left(a_{t+1}, \bar{\epsilon}_{f, t+1}\right)\right)
$$

Hence, optimal hours worked in firm $f$ will be given by:

$$
h_{f, t}=1+\frac{a_{t}-w_{t}+\bar{\epsilon}_{f, t}}{2 \phi}
$$

Notice that the higher is the average level of skill in the firm, i.e. higher $\bar{\varepsilon}_{f}$, the higher will be average hours in the firm. Equation (2) suggests that an aggregate demand shock, i.e. lower $a$, will lead to a fall in average hours worked in the firm.

But, so far we have not considered the employment decision of firms. We assume that the firm decides whether or not to lay off any workers after it has committed to its optimal choice of hours (and that it makes its optimal hours choice without considering the effect on average productivity of future layoffs). If we let the cost of laying-off a worker be given by $\chi$ then the firm will lay off a worker if:

$$
\begin{gathered}
J\left(a_{t}, \varepsilon_{t}, h_{f, t}\right)=\left(a_{t}-w_{t}+\varepsilon_{t}\right) h_{f, t}-\phi\left(h_{f, t}-1\right)^{2}+\beta E J\left(a_{t+1}, \varepsilon_{t+1}, h_{f, t+1}\right)<-\chi \\
\Rightarrow \varepsilon_{t}<w_{t}-a_{t}+\frac{\phi\left(h_{f, t}-1\right)^{2}}{h_{f, t}}-\frac{\beta E J\left(a_{t+1}, \varepsilon_{t+1}, h_{f, t+1}\right)+\chi}{h_{f, t}}=\underline{\varepsilon}
\end{gathered}
$$

Equation (3) defines a threshold level of idiosyncratic productivity denoted as $\underline{\varepsilon}$, below/above which firms will want/will not want to lay off the worker. Clearly, an 
aggregate demand shock (lower $a$ ) will lead to a rise in the threshold level of productivity below which workers are laid off.

We now suppose that there is a state-mandated STW scheme. In particular, if a firm can show that it would otherwise have to lay off a worker, then the state will subsidise a reduction in that worker's hours. In the context of the model, this can be modelled as a subsidy equal to $\theta\left(h_{f, t}-h_{t}\right)$. In this case, the firm will set hours equal to:

$$
h_{s, t}=1+\frac{a_{t}-w_{t}+\bar{\epsilon}_{f, t}-\theta}{2 \phi}=h_{f, t}-\frac{\theta}{2 \phi}
$$

That is, the firm will reduce hours relative to the case where there was no short-time work subsidy. In this case, the firm will lay off a worker if:

$$
J\left(a_{t}, \varepsilon_{t}, h_{s, t}\right)=\left(a_{t}-w_{t}+\epsilon_{t}\right) h_{s, t}-\phi\left(h_{s, t}-1\right)^{2}+\beta E J\left(a_{t+1}, \varepsilon_{t+1}, h_{f, t+1}\right)<-\chi
$$

That is,

$$
\begin{aligned}
\varepsilon_{t} & <w_{t}-a_{t}+\frac{\phi\left(h_{s, t}-1\right)^{2}}{h_{s, t}}-\frac{\beta E J\left(a_{t+1}, \varepsilon_{t+1}, h_{f, t+1}\right)+\chi}{h_{s, t}} \\
& <w_{t}-a_{t}+\frac{\phi\left(h_{f, t}-1\right)^{2}}{h_{f, t}}-\frac{\beta E J\left(a_{t+1}, \varepsilon_{t+1}, h_{f, t+1}\right)+\chi}{h_{f, t}}=\underline{\varepsilon}
\end{aligned}
$$

Equation (5) makes clear that the STW scheme results in fewer layoffs, as the threshold level of idiosyncratic productivity below which workers are laid off has fallen. We can note that a fall in aggregate demand $(a)$ by lowering the firm's optimal choice of hours will increase its use of the subsidy, i.e. make it more likely to take up the scheme. The higher are firing costs $(\chi)$ the lower the threshold level of idiosyncratic productivity below which workers are laid off. So, a given fall in demand will result in fewer workers being laid off, which implies a higher uptake of the STW scheme. Similarly, the more skilled is the firm's workforce, i.e. the higher is $\bar{\varepsilon}_{f}$, the fewer workers will be located below any given level of idiosyncratic productivity. So, again, the more skilled is the workforce, the fewer workers will be laid off in response to a given fall in demand, and the higher will be the uptake of the STW scheme.

In what follows, we use our data to examine whether these features do indeed lead to greater use of STW schemes by firms. We also look at some other firm and country features not captured by this simple model.

\section{Data}

\subsection{Wage Dynamics Network data}

The Wage Dynamics Network (WDN) is a research network of 25 National Central Banks from the European System of Central Banks (ESCB), including both euro area and non-euro area EU Member States. The WDN has been active since 2006, conducting firm surveys in 2007, 2009 and 2014. Further information on the activities of the network is available on the WDN webpage of the ECB, which also includes individual country reports covering most of the countries whose national central banks (NCBs) conducted the firm survey in 2014/2015. 
For this paper, we use firm-level data collected during the third wave of the WDN in 2014/2015; we refer to this as WDN3. Across 25 countries, some 25,000 firms responded to a harmonised 'core' questionnaire that asked how firms were affected by various shocks during the period 2010-2013 and what were the ensuing adjustments to labour inputs (see Izquierdo et al. (2017) for a summary of the main results). The sectors included in the survey were manufacturing (NACE2: $\mathrm{C}$ ), construction (NACE2: F), wholesale and retail trade (NACE2: G), business services (NACE2: H, I, J, L, M and N) and financial services (NACE2: K). Some countries also included other sectors (e.g. utilities, public sector services and arts), which are disregarded for the purpose of this paper, leading to a small reduction in the number of observations. Not only are these sectors not available in all countries, it is also questionable whether employment decisions in these sectors are entirely driven by market forces. Firms were categorised into the following size classes: '1-4 employees' (micro firms), '5-19 employees' (very small firms), '20-49 employees' (small firms), '50-199 employees' (medium-sized firms) and '200+ employees' (large firms). The sample is post-stratified, so that results are representative of either the target population of firms or the number of employees in the target firm population. The sample is representative of the target population of private sector firms (5.5 million in total) and the number of employees in the target firm population (95.4 million).

The questionnaire collected information on firm characteristics as well as qualitative views on economic shocks and firms' adjustment response in terms of labour inputs. Given the cross-country nature of the survey, combined with the recall nature of some of the questions, e.g. firms are asked in 2014 about events and actions between 2010 and 2013the answers to the questionnaire are typically qualitative or binary in nature. A set of detailed questions asked how the firm was affected by various factors, such as the level of demand or access to external financing. For example, the question on demand shocks asked:

'How did the level of demand for your products or services affect your firm's activity during 2010-13?'

Firms could respond with an answer in the following range:

[1] Strong decrease; [2] Moderate decrease; [3] Unchanged; [4] Moderate increase;

[5] Strong increase.

Definitions of all the variables we used, together with summary statistics for each country, are provided in Tables 10, 12 and 13 in the Appendix.

Crucially for the purposes of our study, the section on labour force adjustments included questions on non-subsidised and subsidised reductions in working hours - the latter being our definition of short-time work. Five countries in the survey that did not ask the question Estonia, Latvia, Lithuania, Portugal and the UK - are therefore dropped from the sample. ${ }^{3}$ As Fig. 1 shows, the strong positive correlation between the share of firms experiencing a negative demand shock, be it moderate or strong, in a country and the share of firms reducing their labour inputs follow an Okun-like relationship between labour inputs and output.

Figure 2 shows that where firms reduce labour inputs, more firms reduce the number of employees than reduce hours. Figure 3 shows our measure of STW take-up at the firm-level, which equals one if a firm used subsidised reductions in working hours to 

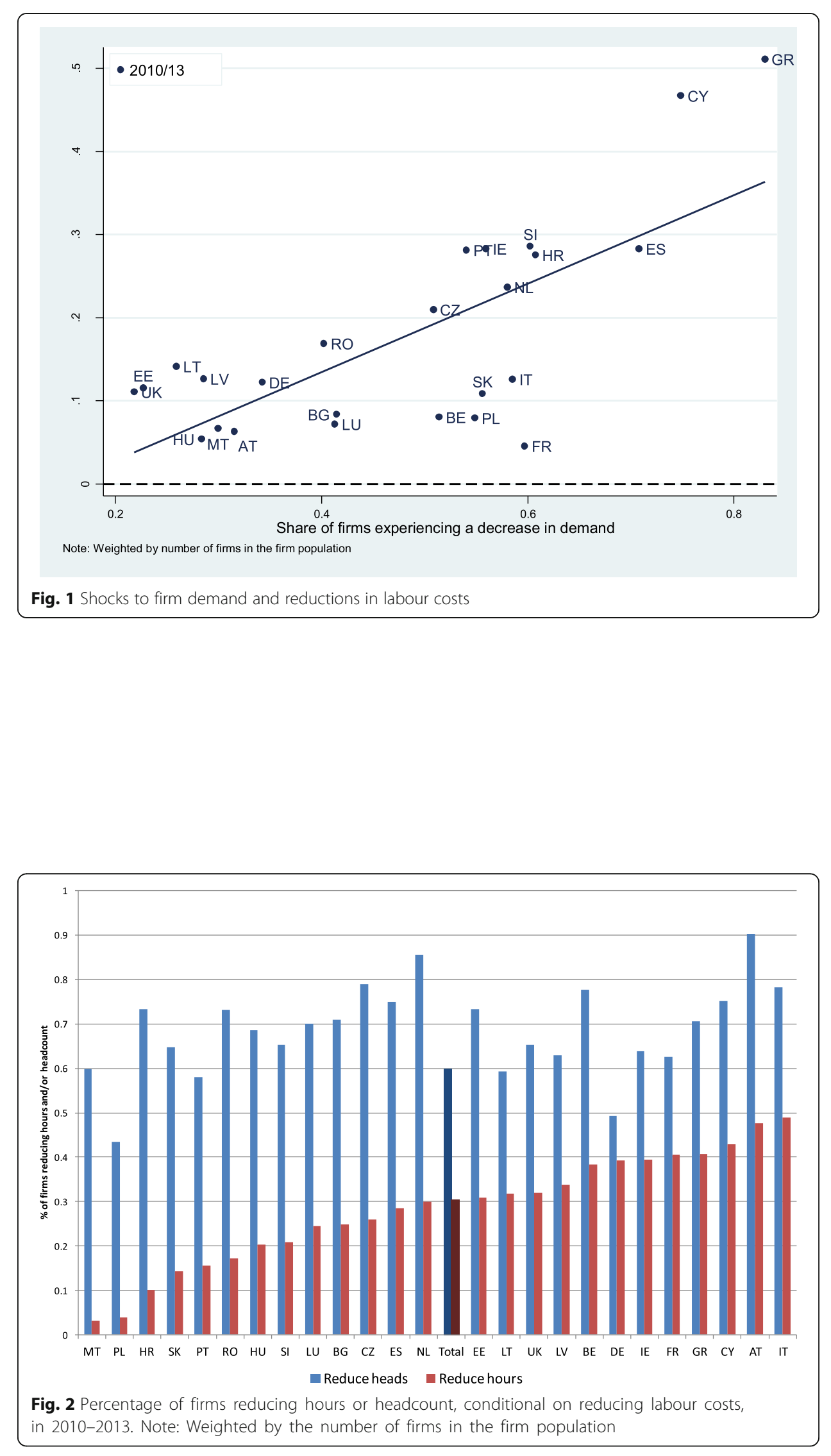


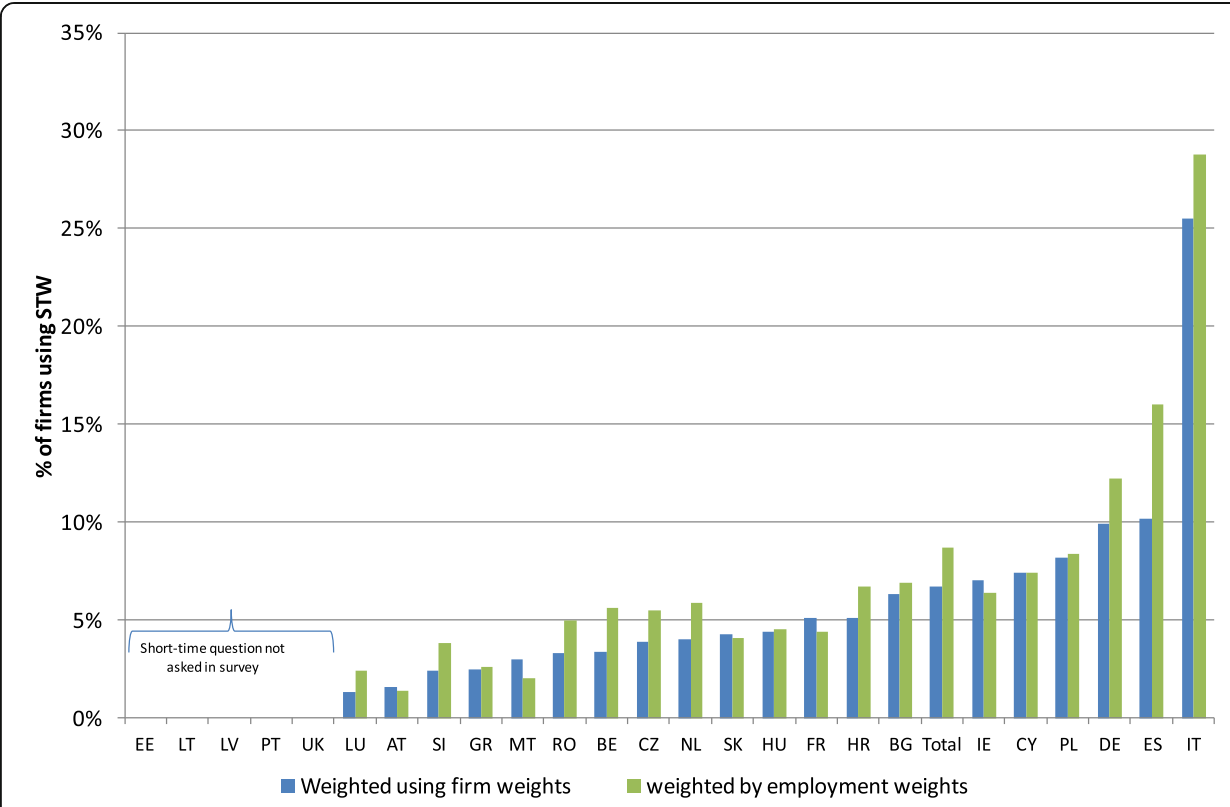

Fig. 3 Share of firms using subsidised reductions in working hours to reduce labour inputs, 2010-2013 (our definition of STW)

adjust labour inputs during the period 2010-2013, and zero otherwise. Across all firms and countries, $6.7 \%$ of firms - also accounting for $8.7 \%$ of workers - used STW schemes. Cross-country heterogeneity is considerable, however, with significantly greater usage in Italy ( $29 \%$ of firms, $27 \%$ of employees), Spain (10\% of firms $16 \%$ of employees) and Germany ( $9 \%$ of firms and $12 \%$ of employees). Similarly, STW take-up is more prevalent in certain sectors, such as manufacturing and construction, as shown in Table 1.

\subsection{Information on STW scheme characteristics}

Drawing on the model predictions above, one of our main aims is to quantify how firm, worker and institutional characteristics affect STW take-up. For example, with the WDN data, we can test whether firms with high levels of firm-specific human capital or firms operating in a country-sector with high hiring and firing costs are more or less likely to use STW. We are, however, conscious of the fact that in a firm-level cross-country dataset, country fixed effects could pick up some of the institutional factors we want to examine. To get around this we draw on the information in the survey papers by Arpaia et al. (2010), Hijzen and Venn (2011) (updated by Hijzen and Martin (2013)) and Boeri and Bruecker (2011) to create a taxonomy of schemes (Table 2). This taxonomy allows us to

Table 1 Short-time work by sector and different weights

\begin{tabular}{|c|c|c|c|c|}
\hline & \multicolumn{2}{|c|}{ Weighted by the number of firms } & \multicolumn{2}{|c|}{ Weighted by employment } \\
\hline & $\%$ of sector in total & $\%$ of firms per sector & $\%$ of sector in total & $\%$ of firms per sector \\
\hline Manufacturing & $23.1 \%$ & $11.5 \%$ & $43.3 \%$ & $14.2 \%$ \\
\hline Construction & $20.1 \%$ & $10.1 \%$ & $9.9 \%$ & $11.8 \%$ \\
\hline Trade & $23.2 \%$ & $5.5 \%$ & $14.4 \%$ & $5.9 \%$ \\
\hline Business services & $32.3 \%$ & $5.1 \%$ & $30.1 \%$ & $6.5 \%$ \\
\hline Financial intermediation & $0.3 \%$ & $1.3 \%$ & $0.5 \%$ & $1.6 \%$ \\
\hline Total & $100.0 \%$ & $6.7 \%$ & $100.0 \%$ & $8.7 \%$ \\
\hline
\end{tabular}


Table 2 Taxonomy of STW schemes

\begin{tabular}{|c|c|c|c|c|c|c|c|}
\hline Country & $\begin{array}{l}\text { Formal } \\
\text { STWA }\end{array}$ & $\begin{array}{l}\text { Operated } \\
\text { via UI }\end{array}$ & $\begin{array}{l}\text { Eligibility } \\
\text { criteria }\end{array}$ & $\begin{array}{l}\text { Response } \\
\text { to crisis }\end{array}$ & If so, when & $\begin{array}{l}\text { Reforms } \\
\text { during } \\
\text { recession }\end{array}$ & $\begin{array}{l}\text { Date of } \\
\text { reform }\end{array}$ \\
\hline AT & Yes & & 3 & & & Yes & 2009 \\
\hline BE & Yes & & 3 & & & Yes & 2008 \\
\hline BG & Yes & & & Yes & 2008 Q1 & & \\
\hline$C Y$ & No & & & & & & \\
\hline$C Z$ & Yes & Yes & 3 & Yes & 2008 Q4 & Yes & 2009 \\
\hline DE & Yes & & 3 & & & Yes & 2009 \\
\hline $\mathrm{EE}$ & No & & & & & & \\
\hline ES & Yes & Yes & 2 & & & Yes & 2009 \\
\hline FR & Yes & & 3 & & & Yes & 2009 \\
\hline GR & No & & 0 & & & & \\
\hline$H R$ & No & & 0 & & & & \\
\hline $\mathrm{HU}$ & Yes & & 1 & Yes & 2009 Q2 & Yes & 2010 \\
\hline IE & Yes & Yes & 0 & & & & \\
\hline IT & Yes & & 1 & & & Yes & 2008 \\
\hline LT & Yes & & & & & Yes & 2009 \\
\hline LU & Yes & & 3 & & & Yes & 2009 \\
\hline LV & Yes & & & & & Yes & 2009 \\
\hline MT & Yes & & & Yes & & & \\
\hline $\mathrm{NL}$ & Yes & & 2 & Yes & 2008 Q4 & Yes & 2008 \\
\hline$P L$ & Yes & & 2 & Yes & 2009 Q3 & Yes & 2009 \\
\hline PT & Yes & & & & & Yes & 2009 \\
\hline $\mathrm{RO}$ & Yes & & & & & Yes & 2009 \\
\hline SI & Yes & & & & & Yes & 2009 \\
\hline SK & Yes & & 2 & Yes & 2009 Q2 & Yes & 2009 \\
\hline UK & No & & & & & & \\
\hline
\end{tabular}

Source: Authors' calculations are based on Hijzen and Venn (2011) and Boeri and Bruecker (2011), Table 11 in Appendix. This is a $0-3$ scale for eligibility criteria: $0=$ loose: $3=$ strict, where 0 means 'none', 1 means a justification is required on economic grounds; 2 means social partner agreement is required; 3 means justification on economic grounds and social partner agreement. Ul: administered via unemployment insurance

introduce country-level controls for institutional factors, such as whether or not a country has a formal, state-run scheme, or the eligibility criteria for schemes. The latter - from the appendix in Boeri and Bruecker (2011) - is a simple count of the categorical and procedural conditions required to activate a scheme in the workplace. ${ }^{4}$

We note from Table 2 that in the Czech Republic, Ireland and Spain, the STW 'schemes' identified by Hijzen and Venn (2011) are effectively a partial social transfer administered by the unemployment benefit system. The budget constraint implied by these systems is, in some ways, more like that associated with income support policies, such as tax credits in the UK. In this sense, the line between STW schemes and income support schemes, including unemployment benefit, becomes quite blurred. In contrast, in other Continental European countries, the various STW schemes are subject to stringent rules and conditions. From an administration perspective, STW schemes in these countries also tend to be entirely separate from the unemployment benefit system. 
As the recession continued, policy-makers in many countries reformed STW schemes to make it easier for both firms and workers to avail of them. We use the account of STW scheme reforms provided in Boeri and Bruecker (2011), along with information in the individual WDN3 country reports to group reforms under three broad headings (along with the countries affected):

Extended coverage: BE, DE, ES, FR, IT, LU, PL, PT, RO - initially, in some countries, scheme coverage was limited to certain sectors or a minimum firm size. Again, as the depth of the recession became clear, coverage was gradually extended to previously uncovered firms and sectors.

- Extended duration: AT, BE, DE, FR, LU, NL, RO, SI, SK - an increasingly popular policy change as the recession wore on.

- Extended compensation: BE, CZ, ES, FR, HU, LT, LU, NL, SI, SK

In our regression analysis, we use information on the different reforms to explain STW take-up at the firm level. However, as Hijzen and Venn (2011) point out, crisis-related reforms are not exogenous events, and therefore our results on reforms should be more correctly interpreted as picking up correlations rather than any causal underlying relationship. Boeri and Bruecker (2011) take a similar approach with their cross-section data by claiming to 'avoid with caution any strict causal interpretation' of the relationship between scheme characteristics and take-up.

\subsection{OECD Employment Protection Legislation (EPL) index}

Our model suggests that STW should be more prevalent in countries with stricter Employment Protection Legislation. Information on EPL measures is available in the OECD EPL Index for most of the countries in our sample. According to the OECD website, the indicators are 'compiled using the Secretariat's own reading of statutory laws, collective bargaining agreements and case law as well as contributions from officials from OECD member countries and advice from country experts'. We include two EPL measures in our regression-an index covering legislation on individual layoffs and an index on collective layoffs.

The WDN also asks firms about perceived hiring and firing costs. Not surprisingly, countries with a high proportion of firms that say firing costs are either a relevant or very relevant issue when it comes to thinking about labour inputs also tend to score highly on the OECD EPL indices, i.e. they have stricter employment protection legislation. Table 13 in the Appendix presents summary statistics for the EPL measures. One advantage of the firm level data is that we can also control for worker tenure in the firm, a factor that tends to be correlated with firing costs when redundancy payments are linked to tenure.

\section{Empirical framework and results}

\subsection{Framework}

In our empirical work, we aim to assess the effects of different variables on the likelihood of STW use by firms. The theoretical model provides clear hypotheses concerning the determinants of STW take-up, which guides our empirical implementation using WDN firm-level survey data. The depen dent variable in our regression analysis equals 
one if a firm used subsidised reductions in working hours during the period 2010-2013 and zero otherwise (see Fig. 3). We use a Logit model to estimate the marginal effect of a given variable on STW take-up. We relate STW take-up to firm and worker characteristics, as well as various aspects of the external environment. The latter includes demand shocks and institutional factors.

Relating to changes in the external environment, we control for shocks to the level of demand and access to finance. ${ }^{5}$ The demand shock takes the value 1 if demand exerted a moderate or strong negative effect on firm's activity in 2010/2013; otherwise, it is zero. Similarly, for a negative access to finance shock. In line with the theoretical model, we expect adverse demand and finance shocks to increase the probability of STW uptake. Figure 4 shows the percentage of firms having experienced each type of shock. Demand shocks tend to dominate, although in some countries there is a high proportion of firms having experienced both shocks. For example, in Greece, Cyprus, Spain and Slovenia 33\% or more of firms experienced both shocks, whereas the same figure for Malta, Estonia, the UK, Latvia and Austria is below 10\%.

The WDN survey includes information on the persistence of the experienced shocks. Conditional on experiencing a strong negative demand shock, firms were also asked whether the shock was transitory, semi-persistent or long-lasting. We have conflicting expectations as to the incremental effects of semi-persistent or long-lasting shocks on STW take-up. Hence, in some of the empirical specifications (e.g. Table 3, specification 5), we explicitly distinguish between different levels of persistence. If, on the one-hand, semi-persistent or long-lasting shocks are merely a proxy for bigger negative demand shocks, then, in line with our model they should be positively correlated with STW take-up. If, on the other hand, firms take 'long-lasting' to mean a permanent negative shock, then this could lead to a negative correlation with STW take-up. This is because, from an efficiency perspective, STW schemes are typically designed so as to avoid take-up where the drop in labour demand is caused by an adverse structural shock (notwithstanding the many reforms to STW schemes during the recession, which effectively relaxed many of these conditions), the idea being to avoid preventing or delaying the re-allocation of labour in response to structural shocks.

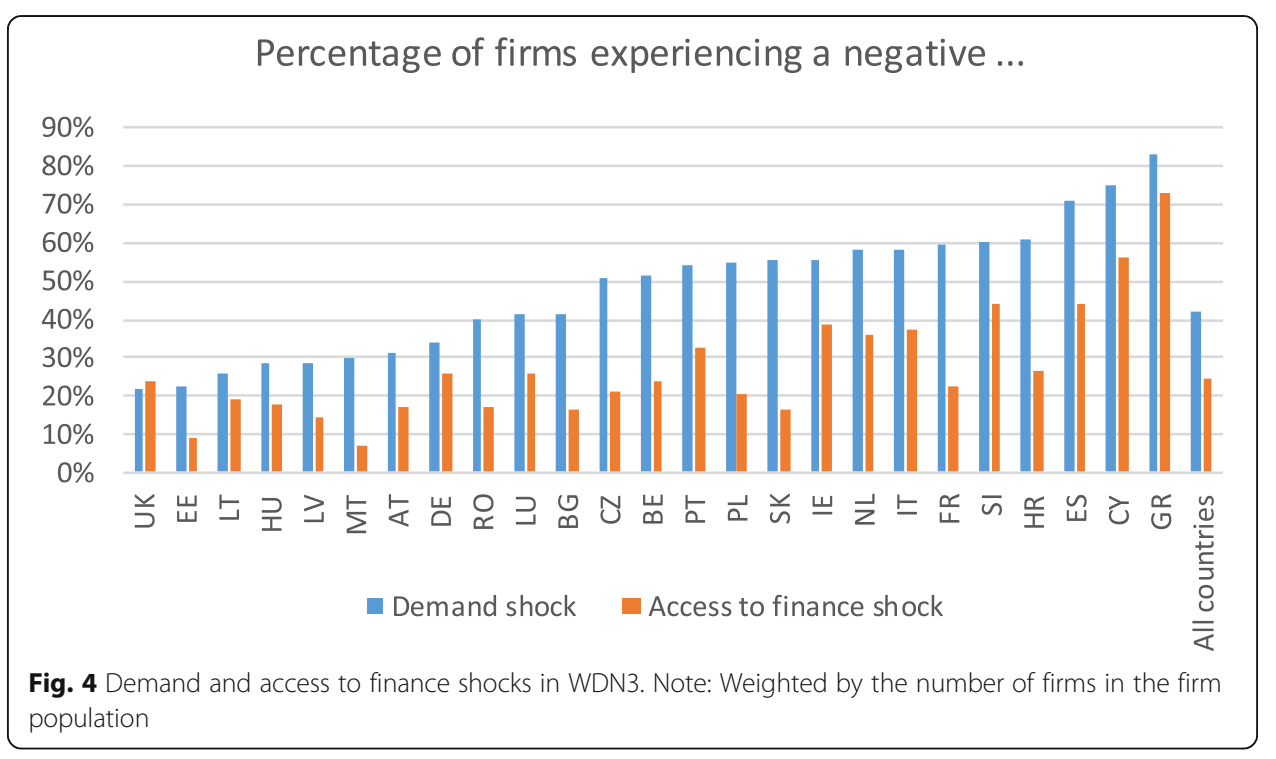


The theoretical model indicates that higher firing costs reduce the threshold level of idiosyncratic productivity below which workers are laid off. So, for a given fall in demand, fewer workers will be laid off, which implies a higher uptake of the STW scheme. Similarly, the more skilled is the firm's workforce the fewer workers will be laid off in response to a given fall in demand and the higher will be the uptake of the STW scheme. The WDN survey includes several firm-specific questions regarding the skill-level and tenure of the workforce, as well as information on hiring and firing costs (see Table 10 in Appendix for a full definition of the variables). Assuming they proxy overall labour market flexibility, the higher these costs are the more likely that STW will be used, ceteris paribus. The shares of full-time and part-time permanent employees (with the base being the share of temporary employees) capture the stability of the labour force in a broad sense, as well as the degree of firm-specific human-capital. In addition, we can think of the share of part-time workers as capturing the degree of existing flexibility in firms' ability to vary hours per worker. The share of employees with tenure of more than 5 years also captures stability and firm-specific human capital. Firms with higher shares of permanent employees and long tenure are expected to be more likely to apply for STW. ${ }^{6}$ In addition, we include two variables capturing the overall skill level of the work force, i.e. the share of high-skilled manual and non-manual workers (using the ISCO-08 classification). Given that STW is typically a phenomenon in manufacturing, we expect the share of high-skilled manual workers in particular to exert a positive effect on STW take-up. Collective pay agreements may constrain the ability of firms to adjust labour flexibly, i.e. shed labour, as social partners and works councils have to agree. That said, if such agreements were negotiated by trade unions that favoured their senior members on a last in, first out (lifo) basis, it is possible that they might result in more layoffs of less senior members rather than in the senior members accepting a (broad-based) loss of income through a STW scheme. Therefore, the application of a pay agreement will exert an ambiguous effect on STW take-up. We included a dummy variable taking the value of 1 if a collective pay agreement of any kind (firm-level or outside the firm) was applied in 2013.

We report the results for various econometric specifications, starting with the most parsimonious specification and successively include country, size and sector fixed effects. Including these controls is likely to render some of the firm-specific variables insignificant. For example, while it is important to control for firm size, as shown in, e.g. Crimmann et al. (2010), this variable is very likely correlated with the probability of having a pay agreement in place. Firm size is included through a dummy variable indicating the respective size class of the firm. The base category is firms employing 1-4 employees, complemented by classes for 5-19, 20-49, 50-199 and 200+ employees. Similarly, we include sector-specific dummy variables to control for sector-specific unobservable characteristics. Again, this may affect the significance of various firm-specific variables, such as the labour share. The base regression also includes country-specific dummy variables, essentially to control for differences in labour market institutions across countries.

In the second step, i.e. after focussing on firms-specific variables only, we augment the specification and include country-specific characteristics of the STW schemes. Variables are whether or not a formal scheme exists, is operated via the 
unemployment insurance system and/or was introduced as a response to the crisis, a variable capturing stringency of the eligibility requirements and some variables capturing changes to STW schemes during the recession, such as increased coverage, duration and compensation. In a third step, we include country-specific characteristics of Employment Protection Legislation. We use the EPL indices from the OECD database. The indices are averages of the years 2010-2013 (where available). We use the combined index for individual and collective dismissals, as well as the index for individual and the index for collective dismissal separately. We expect these indices to be positively correlated with STW take-up. The final take-up specification includes a country-sector-specific measure of downward nominal wage rigidity in the spirit of Dickens et al. (2007). Again, we expect this measure to be positively correlated with STW take-up. Note, the sample can vary slightly depending on the controls we include, as not all information is available for every country. The primary example is the OECD EPL index, which is not available for all of the countries in the WDN dataset.

\subsection{Empirical results - determinants of STW take-up}

\subsubsection{External shocks}

The results (marginal effects) from the estimation are shown in Table 3. As expected, firms experiencing negative demand shocks are significantly more likely to avail themselves of STW schemes. The marginal effect (ranging from 0.051 to 0.064) is large, when the mean of the dependent variable (0.073) is taken into account. Firms that experienced a moderate or strong decrease in their ability to access finance through the usual financial channels are also more likely to avail of STW schemes. This may be picking up additional demand shock factors - firms that experience a negative demand shock may find it more difficult to access external finance for their activities through their usual channels. But, seeing as not all firms experience both shocks (Fig. 4), it might also be the case that a lack of access to short-term finance limits a firm's ability to stabilise inputs in response to demand shocks.

Specifications (2) through (4) incrementally add country, size and sector fixed effects. These additional controls do not affect the coefficients on the two external shock variables. However, as we discuss in the section on firm and worker characteristics below, the inclusion of sector fixed effects does have an effect on some of the worker characteristics. The final specification (5) separates strong negative demand shocks into transitory, semi-persistent and persistent shocks. Relative to moderate shocks, firms experiencing strong negative demand shocks tend to be more likely to take-up STW schemes, regardless of the degree of persistence. Firms experiencing long-lasting negative shocks are significantly more likely to take-up STW schemes (marginal effect of 0.16), which suggests that this is indeed just a proxy for larger negative shocks.

\subsubsection{Worker and firm characteristics}

Our model and other work suggests that firms with a higher proportion of skilled workers, in particular firm-specific human capital are more likely to use STW schemes. We find this to be the case empirically. More specifically, and in line with the results in Boeri and Bruecker (2011), it is the proportion of skilled manual (as opposed to non-manual) workers that 
Table 3 Logit results of STW take-up: firm-specific characteristics (marginal effects)

\begin{tabular}{|c|c|c|c|c|c|}
\hline & (1) & (2) & (3) & (4) & (5) \\
\hline \multicolumn{6}{|l|}{ Shocks } \\
\hline Moderate / strong negative demand shock & $\begin{array}{l}0.0513^{* * *} \\
(0.006)\end{array}$ & $\begin{array}{l}0.0612^{* * *} \\
(0.005)\end{array}$ & $\begin{array}{l}0.0636^{* * *} \\
(0.005)\end{array}$ & $\begin{array}{l}0.0640^{* * *} \\
(0.005)\end{array}$ & \\
\hline Moderate negative demand shock & & & & & $\begin{array}{l}0.0487^{* * *} \\
(0.005)\end{array}$ \\
\hline \multicolumn{6}{|l|}{ Strong negative demand shock } \\
\hline Persistence - Transitory & & & & & $\begin{array}{l}0.1101^{* * *} \\
(0.029)\end{array}$ \\
\hline Persistence - Semi-persistent & & & & & $\begin{array}{l}0.1085^{* * *} \\
(0.016)\end{array}$ \\
\hline Persistence - Long-lasting & & & & & $\begin{array}{l}0.1609^{* * *} \\
(0.015)\end{array}$ \\
\hline $\begin{array}{l}\text { Moderate / strong negative access to } \\
\text { finance shock }\end{array}$ & $\begin{array}{l}0.0257^{* * *} \\
(0.005)\end{array}$ & $\begin{array}{l}0.0278^{* * *} \\
(0.005)\end{array}$ & $\begin{array}{l}0.0288^{* * *} \\
(0.005)\end{array}$ & $\begin{array}{l}0.0280^{* * *} \\
(0.005)\end{array}$ & $\begin{array}{l}0.0231^{* * *} \\
(0.005)\end{array}$ \\
\hline Share high-skilled non-manual employment (\%) & $\begin{array}{l}-0.0259^{* *} \\
(0.011)\end{array}$ & $\begin{array}{l}-0.0255^{* * *} \\
(0.010)\end{array}$ & $\begin{array}{l}-0.0202^{* *} \\
(0.010)\end{array}$ & $\begin{array}{l}-0.0080 \\
(0.010)\end{array}$ & $\begin{array}{l}-0.0086 \\
(0.010)\end{array}$ \\
\hline Share high-skilled manual employment (\%) & $\begin{array}{l}0.0426^{* * *} \\
(0.010)\end{array}$ & $\begin{array}{l}0.0233^{* * *} \\
(0.007)\end{array}$ & $\begin{array}{l}0.0238^{* * *} \\
(0.007)\end{array}$ & $\begin{array}{l}0.0103 \\
(0.007)\end{array}$ & $\begin{array}{l}0.0098 \\
(0.007)\end{array}$ \\
\hline Share of employment with tenure $>5$ years (\%) & $\begin{array}{l}0.0854^{* * *} \\
(0.014)\end{array}$ & $\begin{array}{l}0.0705^{* * *} \\
(0.011)\end{array}$ & $\begin{array}{l}0.0752^{* * *} \\
(0.012)\end{array}$ & $\begin{array}{l}0.0655^{* * *} \\
(0.011)\end{array}$ & $\begin{array}{l}0.0582^{* * *} \\
(0.010)\end{array}$ \\
\hline Has collective pay agreement inside or outside & $\begin{array}{l}0.0086 \\
(0.007)\end{array}$ & $\begin{array}{l}0.0145^{*} \\
(0.008)\end{array}$ & $\begin{array}{l}0.0064 \\
(0.008)\end{array}$ & $\begin{array}{l}0.0034 \\
(0.007)\end{array}$ & $\begin{array}{l}0.0034 \\
(0.007)\end{array}$ \\
\hline $\begin{array}{l}\text { Hiring costs - relevant/very relevant obstacles } \\
\text { for hiring }\end{array}$ & $\begin{array}{l}-0.0067 \\
(0.006)\end{array}$ & $\begin{array}{l}-0.0013 \\
(0.005)\end{array}$ & $\begin{array}{l}-0.0001 \\
(0.005)\end{array}$ & $\begin{array}{l}0.0007 \\
(0.005)\end{array}$ & $\begin{array}{l}0.0005 \\
(0.005)\end{array}$ \\
\hline $\begin{array}{l}\text { Firing costs - relevant/very relevant obstacles } \\
\text { for hiring }\end{array}$ & $\begin{array}{l}0.0271^{* * *} \\
(0.006)\end{array}$ & $\begin{array}{l}0.0324^{* * *} \\
(0.005)\end{array}$ & $\begin{array}{l}0.0328^{* * *} \\
(0.005)\end{array}$ & $\begin{array}{l}0.0318^{* * *} \\
(0.005)\end{array}$ & $\begin{array}{l}0.0303^{* * *} \\
(0.005)\end{array}$ \\
\hline Share of labour costs in firms' total costs (\%) & $\begin{array}{l}0.0002 \\
(0.000)\end{array}$ & $\begin{array}{l}0.0001 \\
(0.000)\end{array}$ & $\begin{array}{l}0.0002^{*} \\
(0.000)\end{array}$ & $\begin{array}{l}0.0003^{* *} \\
(0.000)\end{array}$ & $\begin{array}{l}0.0003^{* *} \\
(0.000)\end{array}$ \\
\hline Share full-time permanent employment (\%) & $\begin{array}{l}-0.0136 \\
(0.013)\end{array}$ & $\begin{array}{l}-0.0126 \\
(0.013)\end{array}$ & $\begin{array}{l}-0.0089 \\
(0.014)\end{array}$ & $\begin{array}{l}-0.0135 \\
(0.014)\end{array}$ & $\begin{array}{l}-0.0136 \\
(0.013)\end{array}$ \\
\hline Share part-time permanent employment (\%) & $\begin{array}{l}0.0334^{*} \\
(0.018)\end{array}$ & $\begin{array}{l}0.0187 \\
(0.017)\end{array}$ & $\begin{array}{l}0.0292 \\
(0.018)\end{array}$ & $\begin{array}{l}0.0450^{* *} \\
(0.018)\end{array}$ & $\begin{array}{l}0.0381^{* *} \\
(0.018)\end{array}$ \\
\hline Irrelevance of insufficiency of labour & $-0.0138^{* *}$ & -0.0062 & -0.0056 & -0.0033 & -0.0081 \\
\hline with the required skills for hiring & $(0.007)$ & $(0.006)$ & $(0.006)$ & $(0.006)$ & $(0.006)$ \\
\hline Country dummies & No & Yes & Yes & Yes & Yes \\
\hline Size dummies & No & No & Yes & Yes & Yes \\
\hline Sector dummies & No & No & No & Yes & Yes \\
\hline Observations & 16,043 & 16,043 & 16,043 & 16,043 & 15,858 \\
\hline Pseudo $R^{2}$ & 0.076 & 0.124 & 0.129 & 0.142 & 0.154 \\
\hline
\end{tabular}

appears to matter. Again, this could reflect the high concentration of STW take-up in manufacturing in the sample. The specifications including sector dummies appear to confirm this: once this sector is controlled for, both variables become insignificant.

We also find that firms with a higher proportion of long-tenured workers, and thus firm-specific human capital, are more likely to avail themselves of STW schemes: a ten percentage point increase in the share of workers with five or more years working in the firm increases the likelihood of STW take-up by $0.6-0.9$ percentage points depending on the specification in question. There is some evidence that firms in which the 
skill-match of an employee is less important for hiring decisions are also less likely to use STW schemes. This result is however not robust to including country, sector and/ or size fixed effects.

If the labour share in total costs is higher, STW take-up also tends to be higher, although the effect is very small: a marginal effect of $0.01-0.03$ percentage points for each $10 \%$ increase in the labour share. The presence of collective pay agreements also increases the probability of STW take-up. This is an indication that STW may increase adjustment flexibility where pay agreements prevail. In particular, collective pay agreements are typically associated with costly and long negotiations over dismissals. The firms, social partners, trade unions and workers councils may well prefer to use STW when jobs are under threat so as to avoid such protracted negotiations. Indeed, below we present evidence that, once we control for the difficulty of bringing about collective dismissals, the 'pay agreements' variable becomes insignificant.

On firing costs, firms were asked how important they are when it comes to making decisions on permanently hiring labour inputs. In line with our model predictions, firms in which firing costs are relevant are significantly more likely (2.7-3.3 percentage points) to take up STW. In contrast, hiring costs do not seem to matter for the take-up of STW. This is a surprising result, as hiring costs would affect the cost of replacing any worker that was laid off and so would act as a strong incentive to maintain employees via a STW scheme. We return to this discussion when we look at EPL in the institutional factors below. We also find that firms with a higher share of part-time workers are more likely to take up STW. The corresponding marginal effect for full-time permanent workers is negative and insignificant. This somewhat puzzling result is however related to a substantial share of firms not having any temporary employees, the base category in these specifications. Excluding firms without temporary employees reduces the sample size to 7775-7736 observations depending on the specification. The marginal effect for permanent employees is $0.028-0.036$ (significant at the $10 \%$ level if standard errors are not clustered) and separating full-time and part-time permanent employees 0.019-0.028 (insignifcant) and 0.065-0.084 (significant at the 5\% level or better), respectively. Still, the estimated marginal effect is roughly 2.5 times larger for part-time permanent employees than for full-time employees. Note though that the mean share of part-time permanent employees in the sample - about 10\% — is rather small (see Table 11 in Appendix).

\subsubsection{Scheme characteristics}

In Table 4, we extend the basic specification to include a range of 'scheme characteristics', including whether or not a 'formal' STW scheme exists in the country. There is a higher rate of STW take-up in countries where there are formal schemes (a marginal effect of around 5.7-7.9 percentage points). Specification (2) includes the measure of eligibility criteria based on Boeri and Bruecker (2011). As expected, the stricter are these criteria, the less likely is STW take-up.

The probability of STW take-up is lower in countries where it is administered via unemployment insurance. This may relate to the replacement rate of unemployment insurance being lower and thus less advantageous than the benefits from STW. STW take-up is also lower in countries that introduced the STW scheme in response to the crisis. As noted by Arpaia et al. (2010), STW schemes in these countries were characterised by wide coverage, strong conditionality for employers and a clear link with 
Table 4 Logit results of STW take-up: Firm-specific characteristics + STW scheme characteristics

\begin{tabular}{|c|c|c|c|}
\hline & (1) & (2) & (3) \\
\hline \multicolumn{4}{|l|}{ Scheme characteristics } \\
\hline Countries with a formal STW scheme & $\begin{array}{l}0.0574^{* * *} \\
(0.019)\end{array}$ & & $\begin{array}{l}0.0789^{* * *} \\
(0.019)\end{array}$ \\
\hline Eligibility criteria & & $\begin{array}{l}-0.0142^{* * *} \\
(0.005)\end{array}$ & \\
\hline Scheme administered through unemployment insurance & $\begin{array}{l}-0.0030 \\
(0.008)\end{array}$ & $\begin{array}{l}-0.0183^{* *} \\
(0.009)\end{array}$ & $\begin{array}{l}-0.0174 \\
(0.012)\end{array}$ \\
\hline Scheme introduced in response to crisis & $\begin{array}{l}-0.0376^{* * *} \\
(0.005)\end{array}$ & $\begin{array}{l}-0.0509^{* * *} \\
(0.011)\end{array}$ & $\begin{array}{l}-0.0198^{*} \\
(0.011)\end{array}$ \\
\hline Crisis induced reform - increase coverage & & & $\begin{array}{l}0.0246^{* * *} \\
(0.009)\end{array}$ \\
\hline Crisis induced reform - extend duration & & & $\begin{array}{l}-0.0419^{* * *} \\
(0.009)\end{array}$ \\
\hline Crisis induced reform - increase compensation & & & $\begin{array}{l}-0.0361^{* * *} \\
(0.0011)\end{array}$ \\
\hline \multicolumn{4}{|l|}{ Shocks } \\
\hline Moderate negative demand shock & $\begin{array}{l}0.0420^{* * *} \\
(0.006)\end{array}$ & $\begin{array}{l}0.0443^{* * *} \\
(0.007)\end{array}$ & $\begin{array}{l}0.0432^{* * *} \\
(0.005)\end{array}$ \\
\hline Transitory strong neg. demand shock & $\begin{array}{l}0.1026^{* * *} \\
(0.030)\end{array}$ & $\begin{array}{l}0.1170^{* * *} \\
(0.035)\end{array}$ & $\begin{array}{l}0.0921^{* * *} \\
(0.028)\end{array}$ \\
\hline Semi-persistent strong neg. demand shock & $\begin{array}{l}0.0982^{* * *} \\
(0.018)\end{array}$ & $\begin{array}{l}0.1114^{* * *} \\
(0.020)\end{array}$ & $\begin{array}{l}0.0951^{* * *} \\
(0.016)\end{array}$ \\
\hline Long-lasting strong neg. demand shock & $\begin{array}{l}0.1210^{* * *} \\
(0.017)\end{array}$ & $\begin{array}{l}0.1311^{\text {****}} \\
(0.020)\end{array}$ & $\begin{array}{l}0.1406^{* * *} \\
(0.016)\end{array}$ \\
\hline Moderate/strong negative access to finance shock & $\begin{array}{l}0.0256^{* * *} \\
(0.005)\end{array}$ & $\begin{array}{l}0.0305^{* * *} \\
(0.006)\end{array}$ & $\begin{array}{l}0.0258^{* * *} \\
(0.005)\end{array}$ \\
\hline Share high-skilled non-manual employment (\%) & $\begin{array}{l}-0.0083 \\
(0.011)\end{array}$ & $\begin{array}{l}0.0014 \\
(0.013)\end{array}$ & $\begin{array}{l}-0.0059 \\
(0.010)\end{array}$ \\
\hline Share high-skilled manual employment (\%) & $\begin{array}{l}0.0213^{* * *} \\
(0.008)\end{array}$ & $\begin{array}{l}0.0274^{* * *} \\
(0.010)\end{array}$ & $\begin{array}{l}0.0151^{* *} \\
(0.007)\end{array}$ \\
\hline Share of employment with tenure $>5$ years (\%) & $\begin{array}{l}0.0759^{* * *} \\
(0.012)\end{array}$ & $\begin{array}{l}0.0817^{* * *} \\
(0.015)\end{array}$ & $\begin{array}{l}0.0695^{* * *} \\
(0.011)\end{array}$ \\
\hline Has collective pay agreement inside or outside & $\begin{array}{l}-0.0082 \\
(0.006)\end{array}$ & $\begin{array}{l}-0.0010 \\
(0.008)\end{array}$ & $\begin{array}{l}0.0022 \\
(0.007)\end{array}$ \\
\hline Hiring costs — relevant/very relevant obstacles for hiring & $\begin{array}{l}-0.0032 \\
(0.005)\end{array}$ & $\begin{array}{l}0.0032 \\
(0.007)\end{array}$ & $\begin{array}{l}-0.0089^{*} \\
(0.005)\end{array}$ \\
\hline Firing costs - relevant/very relevant obstacles for hiring & $\begin{array}{l}0.0252^{* * *} \\
(0.005)\end{array}$ & $\begin{array}{l}0.0190^{* * *} \\
(0.007)\end{array}$ & $\begin{array}{l}0.0266^{* * *} \\
(0.005)\end{array}$ \\
\hline Share of labour costs in firms' total costs (\%) & $\begin{array}{l}0.0003^{* * *} \\
(0.000)\end{array}$ & $\begin{array}{l}0.0002 \\
(0.000)\end{array}$ & $\begin{array}{l}0.0004^{* * *} \\
(0.000)\end{array}$ \\
\hline Share full-time permanent employment (\%) & $\begin{array}{l}-0.0285^{* *} \\
(0.012)\end{array}$ & $\begin{array}{l}-0.0313^{* *} \\
(0.015)\end{array}$ & $\begin{array}{l}-0.0132 \\
(0.014)\end{array}$ \\
\hline Share part-time permanent employment (\%) & $\begin{array}{l}0.0343^{* *} \\
(0.017)\end{array}$ & $\begin{array}{l}0.0362^{*} \\
(0.021)\end{array}$ & $\begin{array}{l}0.0531^{* * *} \\
(0.019)\end{array}$ \\
\hline Irrelevance of insufficiency of labour with the required skills for hiring & $\begin{array}{l}-0.0089 \\
(0.006)\end{array}$ & $\begin{array}{l}-0.0122 \\
(0.008)\end{array}$ & $\begin{array}{l}-0.0101^{*} \\
(0.006)\end{array}$ \\
\hline Size dummies & Yes & Yes & Yes \\
\hline Sector dummies & Yes & Yes & Yes \\
\hline Observations & 15,858 & 11,625 & 15,858 \\
\hline Pseudo $R^{2}$ & 0.107 & 0.112 & 0.128 \\
\hline
\end{tabular}


training provisions (Arpaia et al. 2010, p. 21). In particular, in four countries (the Czech Republic, Hungary, the Netherlands and Slovenia) that recently introduced STW schemes, taking part in training activities was compulsory. Specification (3) looks at STW scheme reforms during the crisis (conditional on a formal scheme being in place). We find that reforms that increased coverage lead, perhaps unsurprisingly, to higher STW take-up whereas reforms that increased worker compensation for hours not worked, i.e. increasing the threshold cost for such schemes, reduced STW take-up.

\subsubsection{Institutional factors: EPL and downward nominal wage rigidity}

STW schemes provide an institutional framework for labour demand adjustment at the intensive margin. Next, we look at the importance of institutional factors in the adoption of STW by firms. In line with the intuition suggested by our model, Boeri and Bruecker (2011) propose a number of testable hypotheses on the relationship between STW and institutions: in particular, they suggest that the demand for STW should be higher in countries with stricter employment protection legislation and more downward nominal wage rigidity, and STW take-up should be decreasing in the generosity of unemployment benefit.

Tables 3 and 4 already included firm-specific variables concerning hiring and firing costs, which are directly related to EPL. The results suggested a significantly positive and robust relationship between firing costs and STW take-up, whereas hiring costs had no influence. The OECD provides various aggregate country-specific EPL indices, which combine different aspects of employment protection, with higher EPL figures indicating stricter legislation. We exchange the firm-specific hiring and firing costs with OECD EPL indices and re-estimate the specification in Table 3. The results - shown in Table 5 - are as we expect: countries with a higher level of EPL also have higher rates of STW take-up. When we split the EPL index into its individual and collective components, we see that it is individual dismissals that seem slightly more important. As we flagged earlier, including the country-specific EPL control renders the 'pay agreement' variable insignificant.

We turn next to the question of whether the demand for STW is higher in those countries with more downward nominal wage rigidity. The WDN survey asks firms about wage cuts and wage freezes each year between 2010 and 2013. Specifically, firms are first asked whether they cut or froze wages, and, secondly, what percentage of workers were affected. We have reason to think that the high-level questions on 'Did the firm cut or freeze wages' tend to be well-answered, whereas the follow-on question on the percentage of

Table 5 Logit results of STW take-up: firm-specific characteristics + EPL indicators

\begin{tabular}{lll}
\hline & $(1)$ & $(2)$ \\
\hline Regulations on dismissals & $0.0378^{* *}$ & \\
Regulations on dismissals (individual) & $(0.017)$ & $0.0201^{*}$ \\
& & $(0.011)$ \\
Regulations on dismissals (collective) & & $0.0179^{* *}$ \\
Observations & & $(0.008)$ \\
Pseudo $R^{2}$ & 13,255 & 13,255 \\
\hline
\end{tabular}

Unweighted average marginal effects reported. Oher variables as in Table 3, but excludes firm-varying hiring and firing costs. Sector and size fixed effects included. The EPL regulations data is OECD data. Standard errors clustered by country, sector and size in parentheses. ${ }^{* * *} p<0.01,{ }^{* *} p<0.05,{ }^{*} p<0.1$ 
workers affected tends not to be. In fact, there is a high degree of non-response to these sub-questions. As a result, results using the measure of wage rigidity that conditions on the percentage of workers affected should be interpreted with some caution.

Drawing on the proposed measures of Downward Nominal Wage Rigidity in Dickens et al. (2007), we construct the following unconditional DNWR measure at the sector $(s)$ and country $(j)$ level:

$$
\mathrm{DNWR}_{s, j}=\frac{\sum[\text { Firms that froze wages }]}{\sum[\text { Firms froze or cut wages }]}
$$

The sectors $(j)$ are manufacturing, construction, trade, business and other services and financial intermediation. We test the relationship between STW take-up and the degree of downward nominal wage rigidity in a Logit model similar to before. Table 6 shows the $D N W R$ coefficients, although the full range of variables is included in each regression.

As wage rigidity may be more or less of a factor depending on the situation a firm finds itself in, we estimate the regression for three samples: (1) the full sample of all firms; (2) the sub-sample of firms that say they had to reduce labour costs during the recession; and (3) the sub-sample of firms that say they reduced labour inputs during the recession. Due to the skewed distribution of this variable, we estimate a specification with dummy variables for different levels of DNWR to allow for threshold and nonlinear effects. ${ }^{7}$ The marginal effects are around 0.06 and 0.08 when we consider the full sample and around 0.05 and 0.13 when we consider the sample of firms that reduce labour costs or and 0.09 and 0.13 when we consider the sample of firms that reduce labour inputs (columns 2 and 3). In other words, in the full sample a rise in the DNWR measure from below 0.5 to a range of [0.5-0.7] would be associated with a rise in STW take-up of around 6 percentage points and further rise to a range of [0.7-1.0] with a further increase by 2 percentage points, i.e. 8 percentage points.

This suggests that it is really in those sectors with higher levels of wage rigidity (DNWR $>0.50$ ) where STW take-up is highest. Comparing the marginal effects with the mean STW take-up in the three samples, ranging from 7.2 to $13.3 \%$ of firms, suggests a significant economic impact. Furthermore, the coefficients are at least as large as those relating firm and scheme characteristics, as shown in Tables 3 and 4. These results suggest that if a firm was in a position where it had to reduce labour costs or inputs during the

Table 6 Logit results of STW take-up: firm-specific characteristics + DNWR measure

\begin{tabular}{|c|c|c|c|}
\hline & $\begin{array}{l}\text { (1) } \\
\text { Full sample }\end{array}$ & $\begin{array}{l}(2) \\
\text { Firms reducing } \\
\text { labour costs }\end{array}$ & $\begin{array}{l}\text { (3) } \\
\text { Firms reducing } \\
\text { labour inputs }\end{array}$ \\
\hline \multicolumn{4}{|l|}{ Dummy variables } \\
\hline DNWR $\leq 0.50$ & [Omitted] & [Omitted] & [Omitted] \\
\hline $0.50<$ DNWR $\leq .70$ & $\begin{array}{l}0.063^{* * *} \\
(0.020)\end{array}$ & $\begin{array}{l}0.0495 \\
(0.045)\end{array}$ & $\begin{array}{l}0.0884^{* *} \\
(0.037)\end{array}$ \\
\hline $0.70<$ DNWR $\leq 1.0$ & $\begin{array}{l}0.0777^{* * *} \\
(0.020)\end{array}$ & $\begin{array}{l}0.1299^{* * *} \\
(0.032)\end{array}$ & $\begin{array}{l}0.1302^{* * *} \\
(0.035)\end{array}$ \\
\hline Observations & 15,707 & 2519 & 5424 \\
\hline $\mathrm{E}(\mathrm{STW})$ & 0.072 & 0.131 & 0.133 \\
\hline
\end{tabular}

Unweighted average marginal effects reported. Other variables as in Table 3. Standard errors clustered by country, sector and size in parentheses. ${ }^{* *} p<0.01,{ }^{* *} p<0.05,{ }^{*} p<0.1$ 
recession, then it is more likely to rely on STW if the sector-country they operate in is characterised by a high degree of downward nominal wage rigidity.

\subsection{The impact of STW take-up}

The preceding analysis has shown how a range of firm, worker and institutional factors combine to affect the take-up of STW across 20 countries. For the policy-maker, the key question is what is the overall impact of STW schemes? That is, how many jobs are 'saved', what are the direct and indirect costs and do they outweigh the benefits (i.e. net effectiveness)? Several papers use the German experience to estimate the likely number of jobs saved. Burda and Hunt (2011) compare the paths of employment and hours across recessions and conclude there was a limited job-saving role for STW during the Great Recession. Using a time-series approach to compare across recessions, Herzog-Stein et al. (2013) find a significant role for working-time reductions (i.e. STW) as a labour saving device, after controlling for cyclical labour productivity. Hijzen and Venn (2011) exploit cross-country differences in the intensity of STW before and during the great recession in a difference-in-difference model and find a significant job-saving role for STW schemes. The authors are careful to point out that they do not quantify the net effectiveness of STW schemes as, among other factors, they do not provide direct estimates of the potential deadweight loss of the schemes. Evidence for Switzerland is provided by Kopp and Siegenthaler (2018) who use quarterly establishment-level panel data and exploit canton-level variation in STW approval rates. They compare the evolution of layoffs, hiring, and employment before and after application for STW and report strong evidence that STW prevents rather than postpones layoffs. Importantly, they argue that the savings from reduced unemployment benefit payments may be large enough to fully compensate the payments related to STW.

Using WDN3 to quantify the job-saving role of STW schemes is not straightforward for several reasons. First, there is no quantitative information on employees or hours worked at the firm level, so direct estimates of the impact on jobs and hours are not available. Second, with a single cross-section, identification of STW effects is challenging. Consequently, the results in this section should be interpreted as being reflective of correlation rather than causal relationships.

To quantify the job-saving potential of STW schemes, we restrict our sample to those firms that reduced labour inputs during the recession. Specifically, we focus on firms that answered yes to the question 'Did you significantly reduce your labour input or alter its composition between 2010 and 2013?' This leaves a sample of just about 5500 firms or around a third of the sample. Within this sub-sample, we identify firms that reduced the number of permanent employees (57\%) and firms that reduced the number of temporary employees (33\%). A sizable minority of firms (27\%) reduce both permanent and temporary employee numbers. We run a regression to test whether STW usage affects the likelihood of a firm reducing employee numbers. ${ }^{8}$ As this is a selected sample of firms, we estimate a maximum-likelihood probit model with sample selection (heckprobit), where the first stage regression (propensity to adjust labour inputs) is instrumented with demand and access to finance shocks. We expect to observe a negative correlation between STW usage and the propensity to layoff permanent workers and no correlation with the propensity to lay off temporary workers, which is indeed 
Table 7 The effect of STW usage on the propensity to lay off workers

\begin{tabular}{|c|c|c|}
\hline Dependent variable & $\begin{array}{l}\text { (1) } \\
\text { Reduce permanent }\end{array}$ & $\begin{array}{l}\text { (2) } \\
\text { Reduce temporary }\end{array}$ \\
\hline Collective layoffs & $\begin{array}{l}0.0956^{* * *} \\
(0.0476)\end{array}$ & $\begin{array}{l}0.0631^{* * *} \\
(0.0133)\end{array}$ \\
\hline Individual layoffs & $\begin{array}{l}0.0861^{* * *} \\
(0.0127)\end{array}$ & $\begin{array}{l}0.0247^{* * *} \\
(0.0150)\end{array}$ \\
\hline Temporary layoffs & $\begin{array}{l}-0.0122 \\
(0.0129)\end{array}$ & $\begin{array}{l}0.0156 \\
(0.0170)\end{array}$ \\
\hline Subsidised reduction of working hours (STW) & $\begin{array}{l}-0.0529^{* * *} \\
(0.0148)\end{array}$ & $\begin{array}{l}-0.0176 \\
(0.0170)\end{array}$ \\
\hline Non-subsidised reduction of working hours & $\begin{array}{l}-0.0172 \\
(0.0108)\end{array}$ & $\begin{array}{l}-0.0300^{* *} \\
(0.0135)\end{array}$ \\
\hline Non-renewal of temporary contracts & $\begin{array}{l}-0.0126 \\
(0.0106)\end{array}$ & $\begin{array}{l}0.1722^{* * *} \\
(0.0177)\end{array}$ \\
\hline Early retirement schemes & $\begin{array}{l}0.0389^{* * *} \\
(0.0120)\end{array}$ & $\begin{array}{l}0.0210 \\
(0.0140)\end{array}$ \\
\hline Freeze or reduction of new hires & $\begin{array}{l}0.0677^{* * *} \\
(0.0111)\end{array}$ & $\begin{array}{l}0.0238^{*} \\
(0.0136)\end{array}$ \\
\hline Reduction of agency workers and others & $\begin{array}{l}0.0262^{* *} \\
(0.0103)\end{array}$ & $\begin{array}{l}0.0701^{* * *} \\
(0.0132)\end{array}$ \\
\hline Firm and worker characteristics & Yes & Yes \\
\hline Sector and size dummies & Yes & Yes \\
\hline Observations & 5508 & 5508 \\
\hline$\%$ firms that laid-off workers & $56 \%$ & $33 \%$ \\
\hline
\end{tabular}

Unweighted average marginal effects reported. The first stage regressors are identical to those of specification (4) in Table 3. Country, sector and size fixed effects included. The second stage includes (not reported) the firm-specific controls hiring and firing costs, collective pay agreement, skill-level (2) and tenure, sector and size fixed effects. Standard errors clustered by country, sector and size in parentheses. ${ }^{* *} p<0.01,{ }^{* *} p<0.05,{ }^{*} p<0.1$

what we find, as shown in Table 7 (we omit presenting the results for the other variables) (this may also be related to the fact that not all firms employ temporary workers.) Firms using STW are around five percentage points less likely to lay off permanent workers, a statistically significant result, but economically not all that large when we consider that more than half of these firms reduced their permanent work-force. Non-subsidised reduction of working hours, however, tends to reduce layoffs of temporary workers. Not surprisingly, other measures reducing labour input or altering its composition either tend to increase layoffs or are insignificant.

Earlier, we showed that STW take-up tends to be concentrated in certain sectors - notably manufacturing and construction - it makes sense, therefore, to consider the effects at the sector level. The results by sector are shown in Table 8 , focusing on reductions in permanent workers as the dependent variable. The correlation for firms in construction is much stronger than the sample average, with lower marginal effects in Manufacturing or Business Services. The effects for Trade are not significant. In addition, the results suggest that temporary layoffs and the non-renewal of temporary contracts help to reduce the layoffs of permanent workers in the Trade and Business services sector, respectively.

The results thus far indicate that STW take-up at the firm level has significant implications for how individual firms' labour demand responds to shocks - but it is unclear whether these effects are significant for employment fluctuations at the aggregate level. To answer this question we relate STW take-up at the country-sector level to employment changes in the same country-sector, controlling for output shocks. The analysis 
Table 8 The effect of STW usage on the propensity to lay off permanent workers

\begin{tabular}{lllll}
\hline Dependent variable & $(1)$ & $(2)$ & $(3)$ & $(4)$ \\
& Manufacturing & Construction & Trade & Business services \\
\hline Collective layoffs & $0.1160^{* *}$ & $0.0955^{* *}$ & $0.0722^{* * *}$ & $0.0984^{* * *}$ \\
& $(0.0285)$ & $(0.0410)$ & $(0.0251)$ & $(0.0270)$ \\
Individual layoffs & $0.0892^{* * *}$ & $0.0889^{* *}$ & $0.0809^{* * *}$ & $0.1105^{* * *}$ \\
& $(0.0193)$ & $(0.0407)$ & $(0.0215)$ & $(0.0294)$ \\
Temporary layoffs & -0.0017 & 0.0202 & $-0.0770^{* * *}$ & 0.0000 \\
& $(0.0204)$ & $(0.0339)$ & $(0.0050)$ & $(0.0246)$ \\
Subsidised reduction of working hours (STW) & $-0.0401^{* *}$ & $-0.2028^{* * *}$ & -0.0050 & $-0.0615^{* *}$ \\
& $(0.0197)$ & $(0.0538)$ & $(0.0225)$ & $(0.0262)$ \\
Non-subsidised reduction of working hours & -0.0071 & -0.0263 & -0.0130 & -0.0181 \\
& $(0.0177)$ & $(0.0335)$ & $(0.0190)$ & $(0.0228)$ \\
Non-renewal of temporary contracts & -0.20203 & $0.0690^{* *}$ & -0.0009 & $-0.0489^{* *}$ \\
Early retirement schemes & $(0.0170)$ & $(0.0363)$ & $(0.0216)$ & $(0.0207)$ \\
& $0.0540^{* * *}$ & $0.0818^{* *}$ & 0.0188 & 0.0307 \\
Freeze or reduction of new hires & $(0.0172)$ & $(0.0363)$ & $(0.0251)$ & $(0.0296)$ \\
Reduction of agency workers and others & 0.0344 & $0.0939^{* *}$ & $0.0716^{* * *}$ & $0.0974^{* * *}$ \\
N & $(0.0230)$ & $(0.0433)$ & $(0.0168)$ & $(0.0183)$ \\
Firm and worker characteristics & 0.0170 & $0.0710^{* *}$ & -0.0090 & $0.0381^{*}$ \\
Size dummies & $(0.0169)$ & $(0.0286)$ & $(0.0240)$ & $(0.0189)$ \\
\hline \% firms that laid-off workers & 1874 & 701 & 1126 & 1679 \\
\hline Tes & Yes & Yes & Yes & Yes \\
& Yes & Yes & Yes & Yes \\
& $57 \%$ & $53 \%$ & $54 \%$ & $55 \%$ \\
\hline
\end{tabular}

The first stage regressors are identical to those of specification (4) in Table 3. Country and size fixed effects included. The second stage includes the firm-specific controls (not reported) hiring and firing costs, collective pay agreement, skill-level (2) and tenure and size fixed effects. Standard errors clustered by country and size in parentheses. ${ }^{* *} p<0.01$, ${ }^{* *} p<0.05,{ }^{*} p<0.1$

proceeds in two stages. In the first stage, we compute a mean STW take-up rate (employment-weighted) at the country-sector (25 countries, 5 sectors: Manufacturing, Construction, Trade, Business Services and Financial Services) level in our WDN data set. In the second stage, we merge this variable with data on quarterly employment and output for the same countries and sectors for the period 2008-13. The latter is from Eurostat; we use the number of employed 15-64year olds for employment and the volume of Gross Value Added (GVA) for output, both by country and sector. We use the period 2008-13 because it overlaps with the WDN reference period, it also captures the negative output and employment shocks during the Great Recession. ${ }^{9}$ In essence, our approach is similar to Herzog-Stein et al. (2013) and Abraham and Houseman (1994, 2014), both of whom show that STW take-up dampens the cyclical variation of employment relative to output in Germany (and France and Belgium in the earlier paper).

The maximum number of observations is 3000 (25 countries, 5 sectors and 24 quarters). However, not all sectors are included in all country surveys, meaning we lose some observations - the main missing sector is Financial Services - and our working sample is $2222 .{ }^{10}$ Figure 5 shows the distribution of the mean STW take-up variable in the merged dataset. Consistent with our summary statistics above, for $44 \%$ of country-sectors in our sample, the take-up rate of STW is less than $2 \%$ (it is zero for $32 \%$ of country-sectors). In the WDN dataset, the take-up rate of STW schemes for Italian construction firms is a very high $80 \%$ (the far-right observation in the chart). 


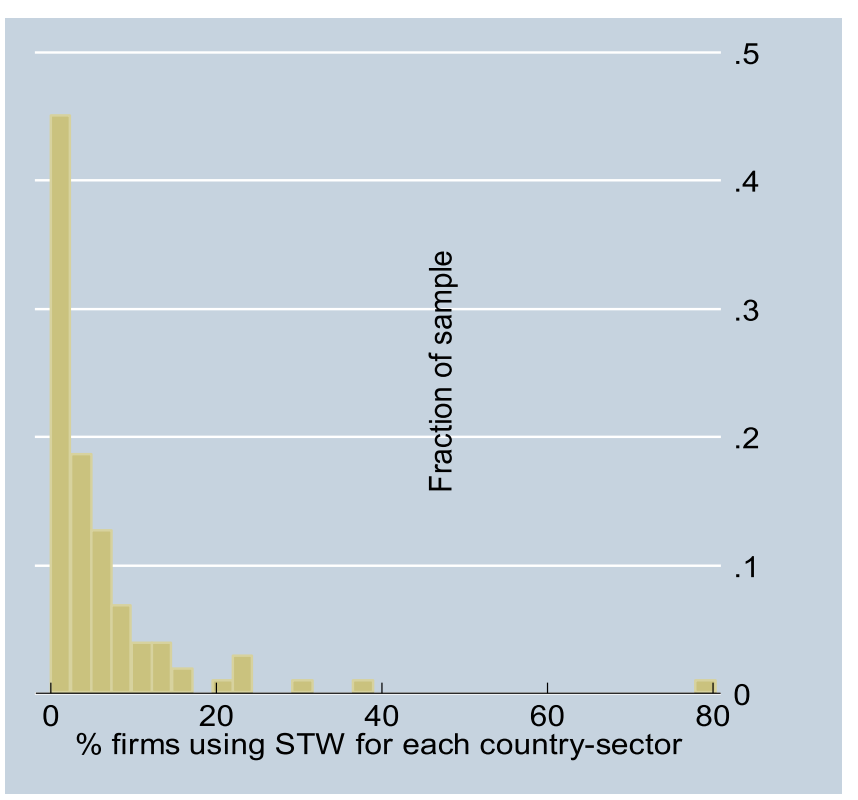

Fig. 5 Distribution of the proportion of firms at the country-sector level using STW

However, given the small cell size (less than 30 firms) we have doubts about the robustness of this figure and therefore omit it from our regressions.

Because output and employment are interdependent, we estimate a panel VAR with these two as endogenous variables. A panel VAR is useful in this setting as not only does it capture short- and longer-run dynamics through the IRFs and cumulative variance decompositions, but it can also be used with a relatively short time series (2008Q1-2013Q4). For identification, we assume that employment affects output with a lag, but output can affect employment contemporaneously. In effect, this means that in the short-run, sectoral output is demand-driven.

Figure 6 (PVAR in log levels) and Fig. 7 (PVAR in annual growth rates) show the impulse response functions. The first chart in each figure shows the IRF for the full sample, while the second chart splits the sample into high- and low-STW sectors. We define high STW sectors as those where $10 \%$ or more of firms used STW during 2010-2013. Low-STW sectors are those where less than $1 \%$ of firms used STW schemes. Table 9 shows the variance decompositions for employment. A clear picture emerges from all of the results: employment in sectors where STW usage is higher is less sensitive to changes in output. The differences are most stark for the PVAR in annual growth rates. In low-/no-STW sectors, a $1 \%$ change in the growth rate of output rapidly feeds through to large employment responses, increasing employment growth by almost $0.4 \%$ after one quarter, with increases persisting long after the initial shock. In 'high'-STW sectors, the response is both smaller and slower, peaking at just under $0.15 \%$ after three-to-four quarters, before fading away. The variance decompositions (Table 9) tell a similar story. For low-STW sectors, output shocks can explain a higher share of the variation in employment compared with high-STW sectors 


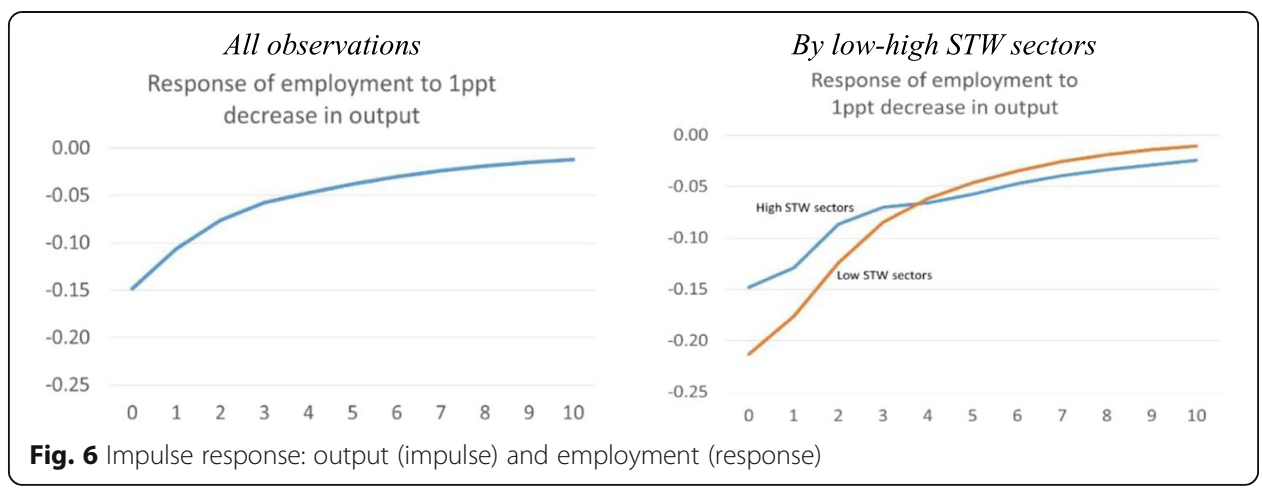

\section{Conclusions}

Using firm-level data from the Wage Dynamics Network survey for 20 EU countries, we analyse the determinants of firms' take-up of short-time work (STWs). We show that firms are more likely to take up STW in response to negative demand shocks. As predicted by theory, we also find that STW take-up is more prominent in firms with higher levels of firm-specific human capital and high firing costs and who operate in countries with stringent employment protection legislation. STW take-up is higher in countries with formalised STW schemes and countries where these schemes were extended in response to the recent crisis. We also find that firms operating in sectors where wages are more rigid are also more likely to use STW as a way of adjusting labour inputs in response to a shock. In addition, we find some evidence that the presence of STW schemes led to a reduction in layoffs, with some sectors, such as manufacturing and construction, benefitting more than others.

Finally, we show that the presence of STW schemes in a large number of countries and sectors has a significant dampening effect on the relationship between employment and output. For sectors where STW is used extensively, the employment to output elasticity can be reduced by as much as one half based on our results. Given the period under investigation, where many countries and sectors experienced substantial negative output shocks in 1 year (2009), our WDN dataset is an ideal candidate for understanding the quantitative importance of STW schemes in preserving employment during a recession. We also find that employment growth during the recovery is lower where STW is used, meaning that STW schemes are an important mechanism for smoothing employment through shocks. This says nothing, however, about the overall welfare effects or efficiency outcomes associated with these schemes.

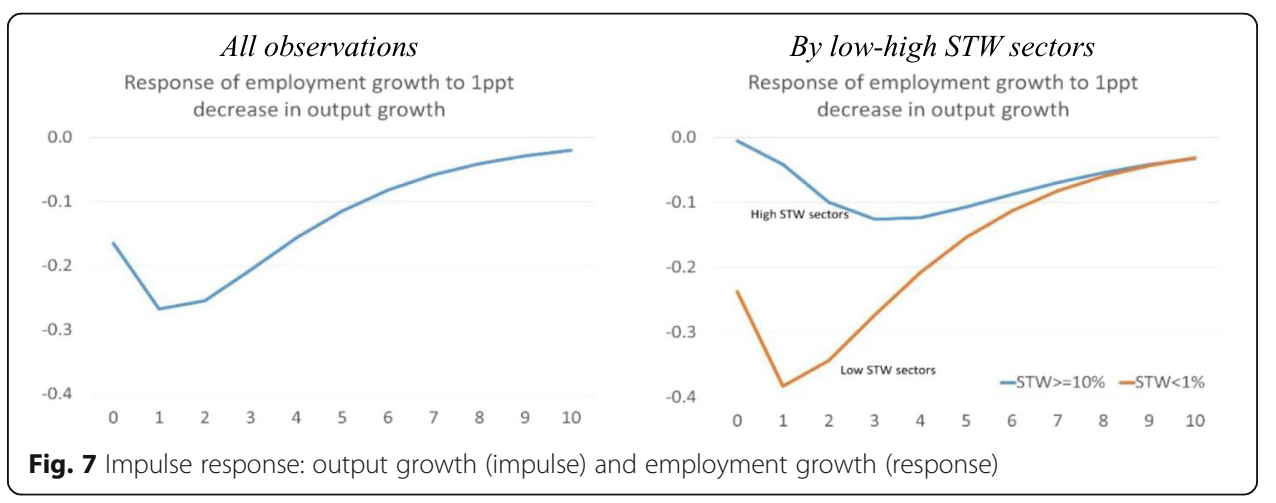


Table 9 Variance decomposition: GVA (impulse): Employment (response)

\begin{tabular}{lll}
\hline & $(1)$ & $(2)$ \\
& Levels (\%) & Growth rates (\%) \\
\hline All & 2 & 14 \\
STW $<1 \%$ & 5 & 26 \\
STW $\geq 10 \%$ & 2 & 3 \\
\hline
\end{tabular}

Variance decompositions from PVAR with employment and output (GVA). The first column is a specification in log levels, the second column annual growth rates. The figures are the cumulative percentage of the variation in employment explained by an output shock after 10 periods

\section{Endnotes}

${ }^{1}$ See the website of the Wage Dynamics Network for further information.

${ }^{2}$ The 'miracle' in question refers to the stability of the German labour market throughout the recession, as illustrated by the fact that total employment actually grew during the recession. See, for example, Rinne and Zimmermann (2013), Herzog-Stein et al. (2013) and Balleer et al. (2016).

${ }^{3}$ In recall surveys such as WDN3, survey designers try to strike a balance between the desire to obtain useful information while at the same time minimising the response burden. In the Baltic countries and the UK, no formal (i.e. State-run) STW schemes exist. The National Central Banks in these countries therefore opted not to ask the question on subsidised reductions in working hours.

${ }^{4}$ The examples in Boeri and Bruecker (2011) are Germany, where worker councils approve the introduction of STW or other countries (like Ireland) where a worker must be on an unemployment insurance scheme. The individual WDN3 country reports contain further details for specific countries.

${ }^{5}$ The survey also asks about shocks to the volatility of demand, customer's ability to pay and the availability of inputs (supply-side factors). However, none of these variables had a significant impact on STW take-up. Results are available on request.

${ }^{6}$ Initially, we also included other firm controls such as whether the firm has multiple establishments, is a parent or domestically owned. However, including these additional controls reduces the German number of observations by about $50 \%$ as not all firms were asked these questions. On the basis of (a) our model makes little prediction as to the importance of these factors; and (b) the large fall-off in the number of German firms, we do not include them in the regressions here.

${ }^{7} \mathrm{~A}$ linear specification of the DNWR variable returns significant positive marginal effects, but only if country, sector and size fixed effects are excluded.

${ }^{8}$ For the purpose of this exercise, we included all 25 countries regardless of whether they asked the question on subsidised reduction of working hours. Those five countries presumably did not ask this question, as STW does not exist in their countries. Hence, for those countries, no STW take up was assumed. The estimation results are robust to changing the sample to the 20 countries in the preceding sections.

${ }^{9}$ We tried alternative time windows, such as 2009-2013 and 2010-2013, but find that our results are not overly sensitive to this choice.

${ }^{10} \mathrm{We}$ also lose a handful of observations with missing employment/output data from Eurostat. 


\section{Appendix}

Table 10 Variable definitions

\begin{tabular}{|c|c|}
\hline Variable & Description \\
\hline \multicolumn{2}{|l|}{ Dependent variable } \\
\hline Used STW & discrete; 1 if used STW, 0 otherwise \\
\hline \multicolumn{2}{|l|}{ Shocks considered } \\
\hline $\begin{array}{l}\text { Level of demand : activity } \\
\text { decreased }\end{array}$ & discrete; 1 if activity decreased moderately or strongly due to the level of demand, 0 otherwise \\
\hline $\begin{array}{l}\text { Level of demand : activity } \\
\text { moderately decreased }\end{array}$ & discrete; 1 if activity decreased moderately due to the level of demand, 0 otherwise \\
\hline $\begin{array}{l}\text { Level of demand : activity } \\
\text { strongly decreased }\end{array}$ & discrete; 1 if activity decreased strongly due to the level of demand, 0 otherwise \\
\hline \multicolumn{2}{|l|}{ Persistence of demand shock } \\
\hline Transitory & $\begin{array}{l}\text { discrete; } 1 \text { if activity decreased strongly due to the level of demand and was perceived as } \\
\text { transitory, } 0 \text { otherwise }\end{array}$ \\
\hline Semi-persistent & $\begin{array}{l}\text { discrete; } 1 \text { if activity decreased strongly due to the level of demand and was perceived as semi- } \\
\text { persistent } 0 \text { otherwise }\end{array}$ \\
\hline Long-lasting & $\begin{array}{l}\text { discrete; } 1 \text { if activity decreased strongly due to the level of demand and was perceived as long- } \\
\text { lasting, } 0 \text { otherwise }\end{array}$ \\
\hline $\begin{array}{l}\text { Access to external financing: } \\
\text { activity decreased }\end{array}$ & $\begin{array}{l}\text { discrete; } 1 \text { if activity decreased moderately or strongly due to the access to external financing, } 0 \\
\text { otherwise }\end{array}$ \\
\hline Labour cost $(\%)$ & continuous, the share labour costs in total costs (all operating expenses) in 2013 \\
\hline Full-time perm. empl., share (\%) & continuous; permanent full-time employees as a share of total employees at the end of 2013 \\
\hline Part-time perm. empl., share (\%) & continuous; permanent part-time employees as a share of total employees at the end of 2013 \\
\hline $\begin{array}{l}\text { High-skill manual workers, share } \\
(\%)\end{array}$ & $\begin{array}{l}\text { continuous; employees belonging to ISCO classes } 7 \text { or } 8 \text { as a share of total employees at the end } \\
\text { of } 2013\end{array}$ \\
\hline $\begin{array}{l}\text { High-skill non-manual workers, } \\
\text { share }(\%)\end{array}$ & $\begin{array}{l}\text { continuous; employees belonging to ISCO classes } 1,2 \text { or } 3 \text { as a share of total employees at the } \\
\text { end of } 2013\end{array}$ \\
\hline Tenure $>5$ years, share $(\%)$ & $\begin{array}{l}\text { continuous; share of employees with job tenure exceeding } 5 \text { years as a share of total employees } \\
\text { at the end of } 2013\end{array}$ \\
\hline Collective pay agreement & $\begin{array}{l}\text { discrete; } 1 \text { if the firm applies a collective pay agreement, either signed at firm level or outside in } \\
2013,0 \text { otherwise }\end{array}$ \\
\hline $\begin{array}{l}\text { Unavailability of skilled labour: } \\
\text { irrelevant }\end{array}$ & $\begin{array}{l}\text { discrete; } 1 \text { if insufficient availability of labour with required skills was irrelevant for hiring } \\
\text { decisions of the firm, } 0 \text { otherwise }\end{array}$ \\
\hline $\begin{array}{l}\text { Relevant hiring obstacle: hiring } \\
\text { costs }\end{array}$ & $\begin{array}{l}\text { discrete; } 1 \text { if firing costs were a relevant/very relevant obstacle in hiring workers with a } \\
\text { permanent, open-ended contracts at the end of } 2013,0 \text { otherwise }\end{array}$ \\
\hline $\begin{array}{l}\text { Relevant hiring obstacle: firing } \\
\text { costs }\end{array}$ & $\begin{array}{l}\text { discrete; } 1 \text { if hiring costs were a relevant/very relevant obstacle in hiring workers with a } \\
\text { permanent, open-ended contracts at the end of } 2013,0 \text { otherwise }\end{array}$ \\
\hline Manufacturing & discrete; 1 if firm belongs to NACE code $\mathrm{C}, 0$ otherwise \\
\hline Construction & discrete; 1 if firm belongs to NACE code F, 0 otherwise \\
\hline Trade & discrete; 1 if firm belongs to NACE code $G, 0$ otherwise \\
\hline Business services & discrete; 1 if firm belongs to NACE codes $\mathrm{H}, \mathrm{I}, \mathrm{J}, \mathrm{L}, \mathrm{M}$ or N, 0 otherwise \\
\hline Financial intermediation & discrete; 1 if firm belongs to NACE code $K, 0$ otherwise \\
\hline 1-4 employees & discrete; 1 if firm had 1-4 employees at the end of 2013, 0 otherwise \\
\hline 5-19 employees & discrete; 1 if firm had 5-19 employees at the end of 2013, 0 otherwise \\
\hline 20-49 employees & discrete; 1 if firm had $20-49$ employees at the end of 2013,0 otherwise \\
\hline 50-199 employees & discrete; 1 if firm had 50-199 employees at the end of 2013,0 otherwise \\
\hline $200+$ employees & discrete; 1 if firm had 200 employees or more at the end of 2013,0 otherwise \\
\hline
\end{tabular}


Table 11 Variable structure

\begin{tabular}{|c|c|c|c|c|c|c|c|c|c|c|c|}
\hline & \multicolumn{2}{|c|}{ Shocks } & \multicolumn{3}{|c|}{ Employee stucture } & \multicolumn{4}{|c|}{ Human captal and shills } & \multicolumn{2}{|c|}{ Obstacles to hining } \\
\hline & $\begin{array}{c}\text { Negative } \\
\text { demand } \\
\text { shock }(\%)\end{array}$ & $\begin{array}{c}\text { Negative } \\
\text { flmance shock } \\
(\%)\end{array}$ & $\begin{array}{c}\text { Labour share, } \\
\%\end{array}$ & 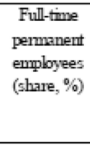 & $\begin{array}{l}\text { Part-tine } \\
\text { penmanent } \\
\text { euployees } \\
\text { (shre, \%) }\end{array}$ & 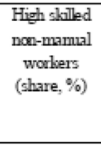 & $\begin{array}{c}\text { High shilied } \\
\text { mamulal } \\
\text { wwakhers } \\
\text { (share, \%) }\end{array}$ & $\begin{array}{c}\text { Irrelevance } \\
\text { of mavali } \\
\text { ablity of } \\
\text { hbour with } \\
\text { required sklk } \\
(\%)\end{array}$ & $\begin{array}{c}\text { Tenure with } \\
\text { more than } 5 \\
\text { years (Ghare, } \\
\% \text { ) }\end{array}$ & $\begin{array}{c}\text { Hiring cost } \\
\text { (relevant } / \\
\text { very rekvant) } \\
\text { (\%) }\end{array}$ & 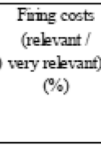 \\
\hline$\overline{\mathrm{AT}}$ & 32.3 & 17.1 & 41.0 & 77.5 & 16.4 & 18.1 & 27.5 & 68.3 & 59.6 & 9.7 & 14.6 \\
\hline $\mathrm{BE}$ & 50.2 & 22.0 & 37.6 & 84.3 & 13.3 & 15.8 & 29.6 & 6.3 & 64.6 & 44.0 & 69.6 \\
\hline BG & 41.7 & 16.7 & 46.7 & 92.5 & 4.0 & 20.4 & 31.9 & 19.4 & 65.1 & 44.0 & 40.0 \\
\hline $\mathrm{CY}$ & 68.0 & 49.7 & 49.3 & 86.7 & 7.6 & 36.7 & 15.7 & 61.6 & 65.9 & 15.8 & 28.1 \\
\hline $\mathrm{cz}$ & 44.0 & 14.5 & 31.1 & 83.5 & 5.0 & 25.7 & 36.1 & 18.9 & 56.0 & 30.5 & 56.5 \\
\hline $\mathrm{DE}$ & 25.5 & 19.6 & 42.9 & 77.9 & 16.2 & 30.4 & 38.1 & 14.2 & 70.4 & 19.4 & 26.6 \\
\hline $\mathrm{EE}$ & 21.7 & 8.0 & 35.1 & 90.6 & 9.1 & 2.0 & 45.2 & 5.7 & 63.1 & 34.4 & 41.6 \\
\hline ES & 70.2 & 44.1 & 41.9 & 72.6 & 11.1 & 18.1 & 30.4 & 31.5 & 620 & 41.1 & 640 \\
\hline $\mathrm{FR}$ & 57.2 & 19.1 & 39.1 & 86.9 & 7.0 & 25.3 & 37.7 & 6.8 & 70.7 & 32.2 & 59.1 \\
\hline$G \mathbb{R}$ & 70.8 & 66.5 & 35.5 & 86.7 & 6.4 & 28.7 & 18.0 & 42.1 & 62.2 & 18.9 & 35.4 \\
\hline $\mathrm{HR}$ & 52.8 & 23.9 & 39.8 & 85.6 & 2.1 & 25.2 & 17.2 & 24.3 & 72.8 & 47.5 & 53.8 \\
\hline $\mathrm{HU}$ & 33.3 & 20.8 & 41.0 & 78.7 & 8.4 & 23.8 & 33.0 & 61.8 & 47.7 & 14.0 & 15.2 \\
\hline $\mathrm{IE}$ & 51.4 & 36.9 & 44.3 & 64.0 & 23.0 & 41.4 & 16.5 & 32.1 & 623 & 39.5 & 41.3 \\
\hline IT & 58.2 & 36.9 & 28.9 & 84.0 & 10.0 & 15.7 & 53.0 & 19.7 & 75.8 & 40.0 & 62.7 \\
\hline LT & 25.0 & 16.3 & 39.9 & 81.3 & 14.8 & 53.9 & 15.2 & 12.6 & 43.6 & 42.1 & 53.0 \\
\hline LU & 35.1 & 21.0 & 47.3 & 84.3 & 12.7 & 29.8 & 28.5 & 17.0 & 60.1 & 33.8 & 46.7 \\
\hline LV & 27.9 & 14.5 & 35.8 & 80.0 & 17.1 & 28.4 & 30.8 & 8.6 & 57.3 & 34.3 & 45.8 \\
\hline MT & 227 & 5.3 & 44.4 & 80.6 & 13.5 & 30.9 & 23.5 & 15.3 & 53.7 & 33.7 & 20.9 \\
\hline NL & 56.1 & 35.4 & 45.2 & 67.8 & 22.7 & 22.0 & 33.7 & 18.8 & 64.2 & 22.4 & 47.0 \\
\hline PL & 41.8 & 18.0 & 30.9 & 70.6 & 7.0 & 34.6 & 25.1 & 7.8 & 61.0 & 74.5 & 68.8 \\
\hline PT & 54.1 & 32.2 & 324 & 77.8 & 1.5 & 26.6 & 34.6 & 0.0 & 61.6 & 46.6 & 65.6 \\
\hline RO & 32.0 & 14.9 & 27.4 & 89.2 & 3.9 & 24.6 & 44.8 & 19.2 & 50.7 & 36.4 & 32.3 \\
\hline SI & 58.5 & 45.1 & 30.0 & 85.5 & 3.3 & 36.1 & 23.2 & 25.3 & 63.6 & 50.6 & 522 \\
\hline SK & 47.2 & 15.0 & 36.3 & 86.9 & 5.1 & 30.1 & 29.9 & 6.1 & 523 & 31.5 & 628 \\
\hline UK & 17.1 & 17.4 & 43.2 & 81.4 & 17.5 & 41.7 & 17.7 & 17.5 & 51.4 & 24.3 & 19.0 \\
\hline Totol & 438 & 253 & 375 & 800 & 103 & 273 & 321 & 229 & 605 & 350 & 453 \\
\hline
\end{tabular}

Table 12 Firm sample structure across countries

\begin{tabular}{|c|c|c|c|c|c|c|c|c|c|c|c|}
\hline \multirow[b]{2}{*}{ Country } & \multirow[b]{2}{*}{$\begin{array}{l}\text { No of } \\
\text { firms }\end{array}$} & \multicolumn{5}{|c|}{ Sector of activity } & \multicolumn{5}{|c|}{ Employment size class } \\
\hline & & Manuf. & Constr. & Trade & $\begin{array}{l}\text { Business } \\
\text { Services }\end{array}$ & $\begin{array}{l}\text { Financial } \\
\text { Intermed. }\end{array}$ & $1-4$ & $5-19$ & $20-49$ & $50-199$ & $>200$ \\
\hline $\mathrm{AT}$ & 784 & 0.29 & 0.11 & 0.22 & 0.32 & 0.06 & 0.01 & 0.18 & 0.21 & 0.32 & 0.28 \\
\hline $\mathrm{BE}$ & 989 & 0.42 & 0.21 & 0.12 & 0.24 & 0.01 & 0 & 0.25 & 0.25 & 0.41 & 0.09 \\
\hline BG & 420 & 0.13 & 0.05 & 0.56 & 0.26 & 0.00 & 0 & 0.68 & 0.21 & 0.08 & 0.02 \\
\hline $\mathrm{CY}$ & 182 & 0.19 & 0.12 & 0.28 & 0.36 & 0.05 & 0.27 & 0.40 & 0.16 & 0.10 & 0.07 \\
\hline $\mathrm{CZ}$ & 1011 & 0.49 & 0.08 & 0.15 & 0.27 & 0 & 0.00 & 0.17 & 0.19 & 0.26 & 0.38 \\
\hline $\mathrm{DE}$ & 2352 & 0.28 & 0.15 & 0.24 & 0.32 & 0.01 & 0.09 & 0.23 & 0.29 & 0.28 & 0.11 \\
\hline $\mathrm{EE}$ & 474 & 0.28 & 0.18 & 0.19 & 0.33 & 0.01 & 0.004 & 0.38 & 0.34 & 0.22 & 0.06 \\
\hline ES & 1957 & 0.26 & 0.00 & 0.31 & 0.44 & 0 & 0 & 0.73 & 0.18 & 0.07 & 0.02 \\
\hline FR & 1156 & 0.44 & 0.15 & 0.22 & 0.20 & 0 & 0 & 0.19 & 0.24 & 0.28 & 0.29 \\
\hline GR & 402 & 0.39 & 0.00 & 0.35 & 0.26 & 0 & 0 & 0.11 & 0.35 & 0.34 & 0.19 \\
\hline HR & 301 & 0.39 & 0.10 & 0.19 & 0.33 & 0 & 0 & 0.30 & 0.28 & 0.33 & 0.10 \\
\hline $\mathrm{HU}$ & 2032 & 0.39 & 0.07 & 0.22 & 0.29 & 0.03 & 0 & 0.12 & 0.30 & 0.40 & 0.19 \\
\hline IE & 1263 & 0.11 & 0.06 & 0.30 & 0.40 & 0.13 & 0.31 & 0.45 & 0.13 & 0.08 & 0.03 \\
\hline IT & 1091 & 0.51 & 0.01 & 0.21 & 0.27 & 0.00 & 0 & 0.07 & 0.52 & 0.29 & 0.12 \\
\hline LT & 515 & 0.15 & 0.12 & 0.33 & 0.30 & 0.11 & 0 & 0.58 & 0.19 & 0.18 & 0.05 \\
\hline LU & 674 & 0.11 & 0.22 & 0.23 & 0.30 & 0.13 & 0.21 & 0.33 & 0.26 & 0.14 & 0.05 \\
\hline LV & 557 & 0.18 & 0.12 & 0.31 & 0.36 & 0.02 & 0 & 0.47 & 0.26 & 0.21 & 0.06 \\
\hline MT & 163 & 0.20 & 0.06 & 0.16 & 0.44 & 0.15 & 0 & 0.14 & 0.25 & 0.36 & 0.25 \\
\hline NL & 727 & 0.25 & 0.14 & 0.24 & 0.34 & 0.03 & 0 & 0.40 & 0.26 & 0.26 & 0.08 \\
\hline PL & 1436 & 0.31 & 0.10 & 0.30 & 0.29 & 0.01 & 0.20 & 0.29 & 0.16 & 0.22 & 0.13 \\
\hline $\mathrm{PT}$ & 1133 & 0.39 & 0.10 & 0.17 & 0.28 & 0.05 & 0 & 0.14 & 0.23 & 0.36 & 0.27 \\
\hline RO & 2043 & 0.54 & 0.11 & 0.14 & 0.21 & 0.00 & 0 & 0.00 & 0.09 & 0.15 & 0.76 \\
\hline SI & 1213 & 0.35 & 0.11 & 0.17 & 0.34 & 0.04 & 0 & 0.51 & 0.19 & 0.19 & 0.11 \\
\hline SK & 604 & 0.32 & 0.09 & 0.21 & 0.34 & 0.04 & 0 & 0.26 & 0.28 & 0.33 & 0.14 \\
\hline UK & 626 & 0.18 & 0.10 & 0.14 & 0.45 & 0.14 & 0.06 & 0.08 & 0.27 & 0.26 & 0.33 \\
\hline Total & 24105 & 0.33 & 0.10 & 0.23 & 0.31 & 0.03 & 0.05 & 0.28 & 0.23 & 0.24 & 0.20 \\
\hline
\end{tabular}


Table 13 Employment Protection indices (OECD-EPL)

\begin{tabular}{cccc}
\hline Country & Individual & Collective & $\begin{array}{c}\text { Individual \& } \\
\text { Collective }\end{array}$ \\
\hline AT & 2.1 & 3.3 & 2.4 \\
BE & 2.2 & 5.1 & 3.1 \\
BG & & & \\
CY & & & \\
CZ & 2.9 & 2.1 & 2.7 \\
DE & 2.5 & 3.6 & 2.8 \\
EE & 1.7 & 2.9 & 2.1 \\
ES & 2.1 & 3.7 & 2.5 \\
FR & 2.6 & 3.4 & 2.8 \\
GR & 2.3 & 3.3 & 2.5 \\
HR & 2.3 & 2.3 & 2.3 \\
HU & 1.7 & 3.4 & 2.2 \\
IE & 1.4 & 3.5 & 2 \\
IT & 2.6 & 4 & 3 \\
LT & 2.2 & 2.9 & 2.4 \\
LU & 2.3 & 3.9 & 2.7 \\
LV & 2.6 & 3.8 & 2.9 \\
MT & & & \\
NL & 2.8 & 3.9 & 2.9 \\
PL & 2.2 & 2.9 & 2.4 \\
PT & 3.5 & 1.9 & 3.1 \\
RO & & & \\
SI & 2.4 & 3.4 & 2.7 \\
SK & 2 & 1.3 & 2.6 \\
UK & 2.3 & 3.3 & \\
Total & & & \\
\hline \hline & & & \\
\hline
\end{tabular}

\section{Abbreviations}

AT: Austria; BE: Belgium; BG: Bulgaria; CY: Cyprus; CZ: Czech Republic; DE: Germany; DNWR: Downward Nominal Wage Rigidity; ECB: European Central Bank; EE: Estonia; EPL: Employment protection legislation; ES: Spain; ESCB: European System of Central Banks; EU: European Union; FR: France; GDP: Gross domestic product; GR: Greece; GVA: Gross Value Added; HR: Croatia; HU: Hungary; IE: Republic of Ireland; iid: Independently and identically distributed; IRF: Impulse response function; ISCO: International Standard Classification of Occupations; IT: Italy; lifo: Last in, first out; LT: Lithuania; LU: Luxembourg; LV: Latvia; MT: Malta; NACE: Nomenclature statistique des activités économiques dans la Communauté européenne; NL: The Netherlands; OECD: Organisation for Economic Co-operation and Development; PL: Poland; PT: Portugal; PVAR: Panel Vector Autoregression; RO: Romania; SI: Slovenia; SK: Slovakia; STW: Short-time work; STWA: Shorttime working arrangement; UI: Unemployment insurance; UK: United Kingdom; US: United States of America; VAR: Vector Autoregression; WDN: Wage Dynamics Network; WDN3: The third wave of the Wage Dynamics Network survey

\section{Acknowledgements}

This paper represents the views of its authors and should not be taken to represent the views of the Central Bank of Ireland, the Banque centrale du Luxembourg, the Bank of England or its policy committees or the European Central Bank.

The authors wish to thank the following people: participants in the ESCB Wage Dynamics Network, for putting together and carrying out the survey, as well as for comments on previous versions of this paper; and participants at the 2017 European Association of Labour Economists conference in St. Gallen, Switzerland, the December 2017 ECB Wage Dynamics Network Conference, in particular our discussant, Pedro Portugal, the 2018 European Economic Association Conference in Cologne and the Labour Market Workshop at the Central Bank of Luxembourg in October 2018. We would like to thank two anonymous referees and the editor for the useful comments.

Responsible editor: Denis Fougère

\section{Funding}

This research was carried out in the course of the authors' regular jobs and not funded by any outside organisation. 


\section{Availability of data and materials}

The data from the Wage Dynamics Network surveys used in this paper has been made publicly available by the European Central Bank and can be requested using the form found on https://www.ecb.europa.eu/home/pdf/ research/wdn/WDN-data_access_request_form.pdf?1 daf263da10aa4b0b1ae8b491cea410d. The data on employment protection legislation measures are available in the OECD EPL Index for most of the countries in our sample. The remaining data can be found in Table 2 in the paper.

\section{Ethics approval and consent to participate}

Not applicable

\section{Consent for publication}

Not applicable

\section{Competing interests}

The IZA Journal of Labor Policy is committed to the IZA Guiding Principles of Research Integrity. The authors declare that they have observed these principles.

\section{Publisher's Note}

Springer Nature remains neutral with regard to jurisdictional claims in published maps and institutional affiliations.

\section{Author details}

${ }_{1}^{1}$ rish Economic Analysis Division, Central Bank of Ireland, Dublin, Ireland. ${ }^{2}$ Banque centrale du Luxembourg, Luxembourg, Luxembourg. ${ }^{3}$ Bank of England, Durham University Business School and Centre for Macroeconomics, Durham, UK.

Received: 21 November 2018 Accepted: 16 January 2019

Published online: 27 February 2019

\section{References}

Abraham KG, Houseman SN (1994) Does employment protection inhibit labor market flexibility? Lessons from Germany, France, and Belgium. In: Blank RM (ed) Social protection versus economic flexibility: is there a trade-off? Chicago University Press, Chicago, pp 59-93

Abraham KG, Houseman SN (2014) Short-time compensation as a tool to mitigate job loss? Evidence on the U.S. experience during the recent recession. Ind Relat 53(4):543-567

Arpaia, A., Curci, N., Meyermans, E., Peschner, J. and Pierini, F. (2010). Short time working arrangements as response to cyclical fluctuation. European Economy. Occasional Papers. June 2010.

Balleer A, Gehrke B, Lechthaler W, Merkl C (2016) Does short-time work save jobs? A business cycle analysis. Eur Econ Rev 84: 99-122

Boeri T, Bruecker H (2011) Short-time work benefits revisited: some lessons from the Great Recession. Econ Policy 26(68):697-765

Brenke K, Rinne U, Zimmermann KF (2013) Short-time work: the German answer to the Great Recession. Int Labour Rev 152(2):287-305

Burda MC, Hunt J (2011) What explains the German labor market miracle in the Great Recession? Brook Pap Econ Act 42(1): 273-336

Burdett K, Wright R (1989) Unemployment insurance and short-time compensation: the effects on layoffs, hours per worker, and wages. J Polit Econ 97(6):1479-1496

Cahuc, P. and S. Nevoux (2017). Inefficient short-time work. CEPR Discussion Paper DP12269, September.

Cooper, R, M. Meyer and I. Schott (2017). The employment and output effects of shorttime work in Germany. Mimeo, August

Crimmann, A., Wießner, F. and Bellmann, L., (2010). The German work-sharing scheme: an instrument for the crisis. ILO

Dickens WT, Goette L, Groshen EL, Holden S, Messina J, Schweitzer ME, Turunen J, Ward ME (2007) How wages change: micro evidence from the International Wage Flexibility Project. J Econ Perspect 21(2):195-214

Efstathiou K, Mathä TY, Veiga C, Wintr L (2018) Short-time work in Luxembourg: evidence from a firm survey. J Labour Mark Res 52(1):14

Herzog-Stein A., Lindner, F., and Sturn, S. (2013). Explaining the German employment miracle in the Great Recession: the crucial role of temporary working time reductions. Technical report, IMK Working Paper

Hijzen A, Martin S (2013) The role of short-time work schemes during the global financial crisis and early recovery: a crosscountry analysis. IZA J Labor Policy 2:5

Hijzen, A. and Venn, D. (2011). The role of short-time work schemes during the 2008-09 recession. OECD Social, Employment and Migration Working Papers 115. OECD Publishing

Izquierdo, M., Jimeno, J.F., Kosma, T., Lamo, A., Millard, S. Rõõm, T. and Viviano, E. (2017). Labour market adjustment in Europe during the crisis: microeconomic evidence from the Wage Dynamics Network survey. ECB Occasional paper 192

Kopp, D. and Siegenthaler M. (2018). Does short-time work prevent unemployment?, Mimeo. January 2018

Möller J (2010) The German labor market response in the world recession: de-mystifying a miracle. J Labour Mark Res 42(4): $325-336$

Oi WY (1962) Labor as a quasi-fixed factor. J Polit Econ 70(6):538-555

Rinne U, Zimmermann KF (2013) Is Germany the north star of labor market policy? IMF Econ Rev 61 (4):702-729

Van Audenrode MA (1994) Short-time compensation, job security, and employment contracts: evidence from selected OECD countries. J Polit Econ 102(1):76-102 